\title{
Clinical and OCT outcomes of a universal adhesive in a randomized clinical trial after 12 months
}

\author{
Dissertation \\ zur Erlangung des akademischen Grades \\ Dr. med. dent.
}

an der Medizinischen Fakultät

der Universität Leipzig

eingereicht von: Marcus Hähnel

Geburtsdatum: $\quad$ 28.02.1993

Geburtsort: Quedlinburg

angefertigt an: Universität Leipzig, Poliklinik für Zahnerhaltung und Parodontologie

Betreuer: $\quad$ Univ.-Prof. Dr. med. dent. Rainer Haak, MME

Dr. rer. nat. Hartmut Schneider

Beschluss über die Verleihung des Doktorgrades vom 08.09.2020 


\section{Inhaltsverzeichnis}

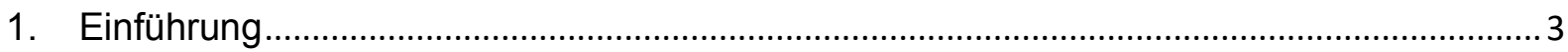

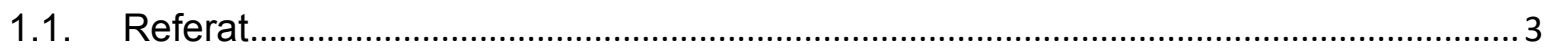



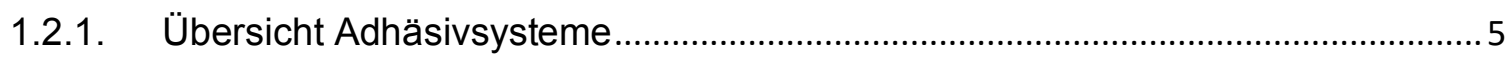

1.2.2. Methoden zur Bewertung von Adhäsivsystemen ............................................... 7

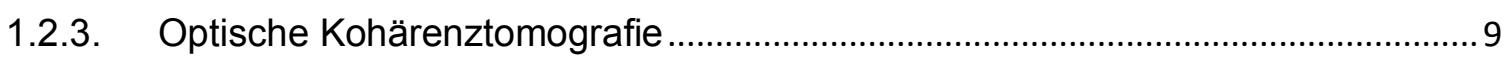

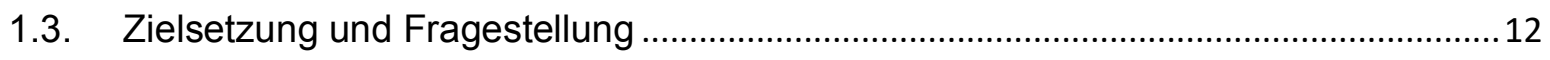

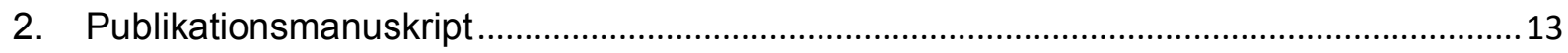

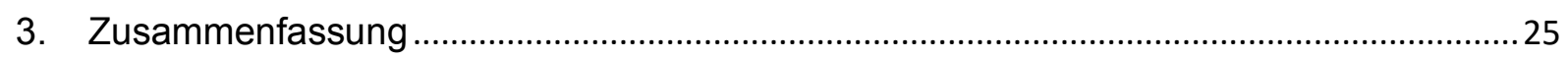

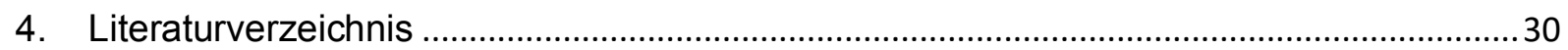

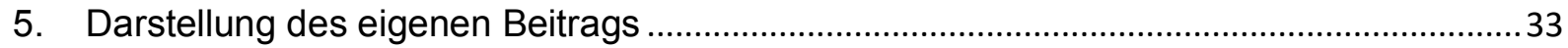

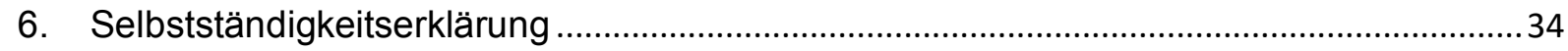

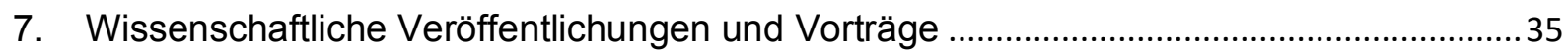

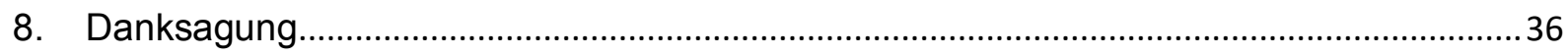




\section{Einführung}

\section{Bibliografische Beschreibung}

Marcus Hähnel

Titel der Arbeit

Clinical and OCT outcomes of a universal adhesive in a randomized clinical trial after 12 months

Universität Leipzig, Dissertation

37 Seiten, 45 Literaturquellen, 1 Abbildung

\subsection{Referat}

Das Ziel der vorliegenden randomisierten, klinisch kontrollierten, prospektiven Studie war es, die Leistungsfähigkeit des Universaladhäsivs ЗМтм Scotchbondтм Universal (SBU) bei dessen Anwendung an nicht kariösen Zahnhalsläsionen (NCCL) klinisch und mit optischer Kohärenztomografie (OCT) zu bewerten. An 55 Patienten wurde das Universaladhäsiv in den Konditionierungsmodi self-etch (SE, $n=55$ ), selective-enamel-etch $(\mathrm{SEE}, \mathrm{n}=55$ ) und etch-and-rinse $(E R, n=55)$ in Kombination mit dem Komposit Filtek ${ }^{\mathrm{TM}}$ Supreme $\mathrm{XTE}$ angewendet. Das etablierte Etch-and-rinse-Adhäsiv OptiBond ${ }^{\mathrm{TM}} \mathrm{FL}$ (OFL) diente als Referenzsystem ( $\mathrm{n}=55)$. Die Restaurationen wurden nach 14 Tagen (Baseline), sechs und 12 Monaten klinisch untersucht (FDI-Kriterien). Parallel dazu erfolgte die quantitative Bewertung der interfazialen Spaltformationen am Schmelz und Dentin/Zement mit OCT, welche erstmals bereits direkt nach Füllungslegung vorgenommen wurde. Die kumulativen Fehlerraten (CFR), die klinischen Parameter Randverfärbung, Randadaptation und Frakturen/Retention, sowie die gemittelten adhäsiven Defekte pro Gruppe wurden statistisch 
ausgewertet. Nach 12 Monaten ergaben sich in allen Gruppen mit SBU signifikant geringere kumulative Fehlerraten als in der Kontrollgruppe OFL. Unmittelbar nach Füllungslegung sowie nach sechs und 12 Monaten konnten an der Schmelz-Komposit-Interface in der Gruppe SBU/SE mehr adhäsive Defekte als in den Gruppen SBU/SEE und OFL nachgewiesen werden. An der dominierenden Dentin/Zement-Komposit-Interface zeigte sich hingegen in der Gruppe OFL generell ein signifikant höheres Verbundversagen. Sowohl die klinische als auch die tomografische Bewertung ergaben ein geringeres Verbundversagen in den Gruppen mit SBU im Vergleich zu OFL. Dabei resultierte auch aus der unbeabsichtigten Phosphorsäureätzung am Dentin bei selektiver Schmelzätzung kein Nachteil. Mit OCT konnten signifikante Gruppenunterschiede früher als mit der klinischen Bewertung, nämlich bereits unmittelbar nach Füllungslegung, dargestellt und reproduziert werden. Das verdeutlicht die hohe Sensitivität und Reliabilität der Methode zur Bewertung des ZahnKomposit-Verbundes und lässt sehr viel frühere Aussagen zur klinischen Bewährung von Systemen zur Restauration mit Kompositen zu. 


\subsection{Einführung in die Thematik}

\subsection{1. Übersicht Adhäsivsysteme}

Seit der schrittweisen Etablierung der Adhäsivtechnik in der Zahnmedizin mit der Einführung der Phosphorsäurekonditionierung des Zahnschmelzes im Jahre 1955 [1] ist die Verbundzone Komposit-Zahn immer wieder als eine Schwachstelle in der adhäsiven Zahnheilkunde identifiziert worden [2,3]. Die aktuellen Adhäsivsysteme werden in Etch-andrinse- und Self-etch-Adhäsive unterteilt. Die erforderlichen Konditionierungsschritte werden bei den Etch-and-rinse-Adhäsiven entweder in drei oder in zwei Schritten durchgeführt, während die selbstkonditionierenden Systeme als „1-Schritt“- und „2-Schritt“-Adhäsive angeboten werden [3].

Mit der Etablierung der selbstätzenden Adhäsive und deren stetiger Weiterentwicklung, ergab sich eine ernstzunehmende Alternative zu den etablierten Etch-and-rinse-Adhäsiven. Deren vereinfachte Handhabung und die daraus resultierende geringere Fehleranfälligkeit bei der Anwendung, verhalfen dieser Adhäsivgruppe zu einer immer breiteren klinischen Anwendung [4]. In Abhängigkeit vom pH-Wert werden die selbstätzenden Systeme in „stark" $(\mathrm{pH}<1)$, „mittelstark“ $(\mathrm{pH} \approx 1,5)$, „mild“ $(\mathrm{pH} \approx 2)$ und „ultra-mild“ $(\mathrm{pH} \geq 2,5)$ unterteilt $[2,3]$. Mithilfe der enthaltenen sauren Monomermischungen sind die selbstätzenden Adhäsivsysteme in der Lage, ein reduziertes Ätzmuster im Schmelz zu erzeugen. Für den dauerhaften mikromechanischen Verbund zum Schmelz, wird jedoch dessen zusätzliche selektive Konditionierung mit Phosphorsäure empfohlen [5,6]. Dabei konnte nachgewiesen werden, dass sich eine zusätzliche Konditionierung des Dentins bei selbstätzenden Systemen nachteilig auswirkt [7].

Bei der Dentinhaftung ergibt sich mit selbstätzenden Adhäsiven ein klarer Vorteil: Eine Überätzung, verbunden mit dem Risiko des Kollabierens des Kollagennetzwerkes, kann im Unterschied zur Anwendung von Etch-and-rinse-Adhäsiven, weitestgehend vermieden werden. Die damit verbundene unvollständige Penetration von Adhäsivmonomeren in das 
Kollagennetzwerk des konditionierten Dentins, welche als Phänomen des „Nanoleakage“ klinisch mit vermehrten Auftreten postoperativer Hypersensitivitäten einhergeht, stellt dadurch ein deutlich geringeres Problem dar $[8,9]$.

Zur weiteren Vereinfachung der Handhabung von selbstkonditionierenden Adhäsiven, wurden aus den ursprünglichen 2-Komponentensystemen als 2-Schrittsystem Einflaschensysteme entwickelt (All-in-one-Adhäsive), welche Self-etch-Primer und Adhäsiv vereinen. Es erfolgt eine Integration der aufgelösten Schmierschicht und der anorganischen Bestandteile in die Hybridschicht $[10,11]$.

\section{Universaladhäsive}

Auf Grundlage dieser 1-Schritt-Adhäsive erfolgte die Weiterentwicklung hin zu den Universaladhäsiven, welche seit 2011 auf dem Dentalmarkt vertreten sind und dessen erster Vertreter das Scotchbond Universal Adhäsiv war [12-14]. Ein wesentliches Merkmal dieses Adhäsivtyps besteht in der Möglichkeit der Anwendung in allen drei Konditionierungsmodi: selbstätzend (self-etch), selektive Schmelzätzung (selective-enamel-etch) und etch-andrinse. Außerdem können einige Universaladhäsive ohne zusätzliches Priming bei der adhäsiven Befestigung von Zirkon- und Glaskeramikwerkstoffen verwendet werden [14]. Die meisten dieser Systeme enthalten das funktionelle Monomer 10-MDP [15,16]. Dieses gewährleistet nicht nur eine ausgeprägte chemische Bindung an das Hydroxylapatit der Zahnhartsubstanzen, die lonenbindung mit Kalzium ist auch hydrolytisch stabiler im Vergleich zu 4-MET oder Phenyl-P [16]. In vivo [17] und in vitro $[14,18,19]$ konnte gezeigt werden, dass die Anwendung von Scotchbond Universal am Dentin mit allen Ätzprotokollen erfolgen kann. 


\subsubsection{Methoden zur Bewertung von Adhäsivsystemen}

Weil die Verbundzone zwischen Zahnhartsubstanz und Komposit eine Schwachstelle darstellt, ist deren Analyse bei der Bewertung von Adhäsivsystemen von besonderer Bedeutung. Physikalische Beanspruchung und chemische Degradation führen zu einer Beeinträchtigung des Zahn-Komposit-Verbunds und gehen mit Randverfärbungen, Überempfindlichkeiten, Karies am Restaurationsrand und Füllungsverlusten einher [20-22].

Zur Detektion interfazialer adhäsiver Defekte als Parameter für ein Zahn-KompositVerbundversagen sind zahlreiche Verfahren beschrieben wurden. In-vitro-Untersuchungen basieren meist auf invasiven Methoden wie Licht- und Rasterelektronenmikroskopie sowie auf der Mikroleakage-Analyse. Bei Letzterer wird unter Anwendung von Farbstoffen deren Penetration durch den interfazialen Spalt gemessen. Ein großer Nachteil der o.g. Methoden ist die invasive Vorgehensweise, welche nach Herstellung von Schliffpräparaten nur eine zweidimensionale Darstellung erlaubt. Zudem kann es bei diesem Verfahren zu Artefakten kommen, die Spaltformationen vortäuschen [23]. In-vitro-Untersuchungen haben einen weiteren Nachteil: Die Performance der zu untersuchenden Adhäsivsysteme kann lediglich unter mehr oder weniger simulierten klinischen Bedingungen untersucht werden, welche die Realität immer nur sehr eingeschränkt abbilden. Ferner besteht keine Möglichkeit, das Verbundversagen longitudinal darzustellen und an demselben Objekt und denselben Schnittbildebenen zu quantifizieren [24-28]. In vivo ist, basierend auf der Herstellung von Repliken, die quantitative und qualitative Bewertung des Zahn-Füllung-Verbundes am Restaurationsrand mit Licht-und Rasterelektronenmikroskopie möglich. Dieses Verfahren ist jedoch aufwändig und erlaubt nur die Bewertung der zugänglichen Restaurationsrandbereiche [29]. Eine röntgenologische Beschreibung der Spaltformationen ist ebenfalls beschrieben wurden, birgt jedoch eine Vielzahl von Fehlerquellen in sich, u.a. das Radioluzenzverhalten von Adhäsiv und Komposit und den Projektionswinkel [30].

Klinische Studien benötigen z.T. große Patientenzahlen und lange Nachuntersuchungszeiten, um das aus den FDI-Kriterien abzuleitende klinische Versagen 
darzustellen [17,31]. Mit einem nicht-invasiven hochauflösenden bildgebenden Verfahren könnten zusätzlich zu den klinischen Kriterien wesentliche Informationen zum ZahnKomposit-Verbundversagen generiert werden. In zahlreichen Studien wurde gezeigt, dass OCT das leisten kann [32,33].

Bei der Bewertung des Universaladhäsivs Scotchbond Universal wurden in der vorliegenden Studie nichtkariöse Klasse-V-Läsionen herangezogen, da sie zur Bewertung von Adhäsivsystemen aus folgenden Gründen besonders geeignet sind:

1. Durch das Fehlen makromechanischer Retentionen fallen adhäsive Defekte schneller in Form von Restaurationsverlusten auf.

2. Die Restaurationsränder umfassen im Idealfall alle Zahnhartsubstanzen (Schmelz, Dentin, Zement).

3. Sie bieten anatomisch bedingt einen guten Zugang zu diagnostischen Verfahren.

4. Sie sind relativ häufig verbreitet und erleichtern damit die Patientenauswahl.

5. Der Einfluss der mechanischen Eigenschaften des verwendeten Komposits verringert sich bedingt durch einen kleinen C-Faktor.

Aufgrund dieser Faktoren wird das klinische Ergebnis primär durch das verwendete Adhäsiv bestimmt [3]. 


\subsubsection{Optische Kohärenztomografie}

Die OCT ist ein nicht-invasives Verfahren zur Darstellung von Objektoberflächen. Inhärente Strukturen können am Zahnschmelz mit hoher örtlicher Auflösung bis in eine Tiefe von $3 \mathrm{~mm}$ dargestellt werden (Zentralwellenlänge 1300-1550 nm). Die auf Weißlichtinterferometrie basierende Methode wurde 1991 von Huang et al. eingeführt [34]. Mit einer axialen Auflösung von einigen Mikrometern (Luft) ordnet sich dieses Verfahren zwischen der Konfokalmikroskopie und der Sonografie ein. Die erste Generation von OCT-Systemen basiert auf der Time-domain (TD-OCT) Detektion. Dieses Verfahren wurde weitestgehend durch die Fourier-domain- bzw. Spectral-domain-OCT (SD-OCT) abgelöst. Dadurch wurden deutlich höhere Scangeschwindigkeiten erzielt. Die Polarisationssensitive-OCT (PS-OCT) erlaubt darüber hinaus weitere strukturelle Differenzierungen [35]. Mit OCT ist es möglich, 2D- und 3D-Bildgebung an Zahnhartsubstanzen und oralen Weichgeweben beliebig oft durchzuführen, da die Abbildung keine Strahlenschäden verursacht [36].

\section{Funktionsweise}

Die nachfolgend beschriebene Funktionsweise bezieht sich auf die in der Studie verwendete Spectral-domain-OCT (SD-OCT). Das Licht einer Superlumineszenzdiode wird über einen Strahlenteiler in einen Proben- und einen Referenzarm geteilt und dem Objekt bzw. einem Spiegel zugeführt. Beide Strahlen tasten dabei eine Fläche von $10 \mathrm{~mm} \times 10 \mathrm{~mm}$ punkt- und zeilenweise ab. An der Probenoberfläche und inhärenten Strukturen wie Poren oder Spalten und an Grenzflächen zwischen verschiedenen Materialien wird das Licht des Probenarmes gestreut, gebrochen, reflektiert und teilweise absorbiert. Nach Umlenkung werden die beiden in der Phase und Amplitude verschiedenen Strahlen zur Überlagerung gebracht und detektiert. Aus dem Laufzeit- und Amplitudenunterschied beider Teilstrahlen resultieren dann strukturspezifische Interferenzsignale. Zu jedem Objektpunkt lassen sich die entlang einer Linie senkrecht zur Objektoberfläche enthaltenen Strukturen den Interferenzsignalen zuordnen, woraus sich ein Tiefenprofil dieser Strukturen ergibt (A-Scan, 
Fouriertransformation). Die A-Scans entlang einer Linie (Zeile) ergeben folglich ein Schnittbild (B-Scan) und viele Schnittbilder einen 3D-Bilderstapel (C-Scan) [37,38]. (Abb. 1).

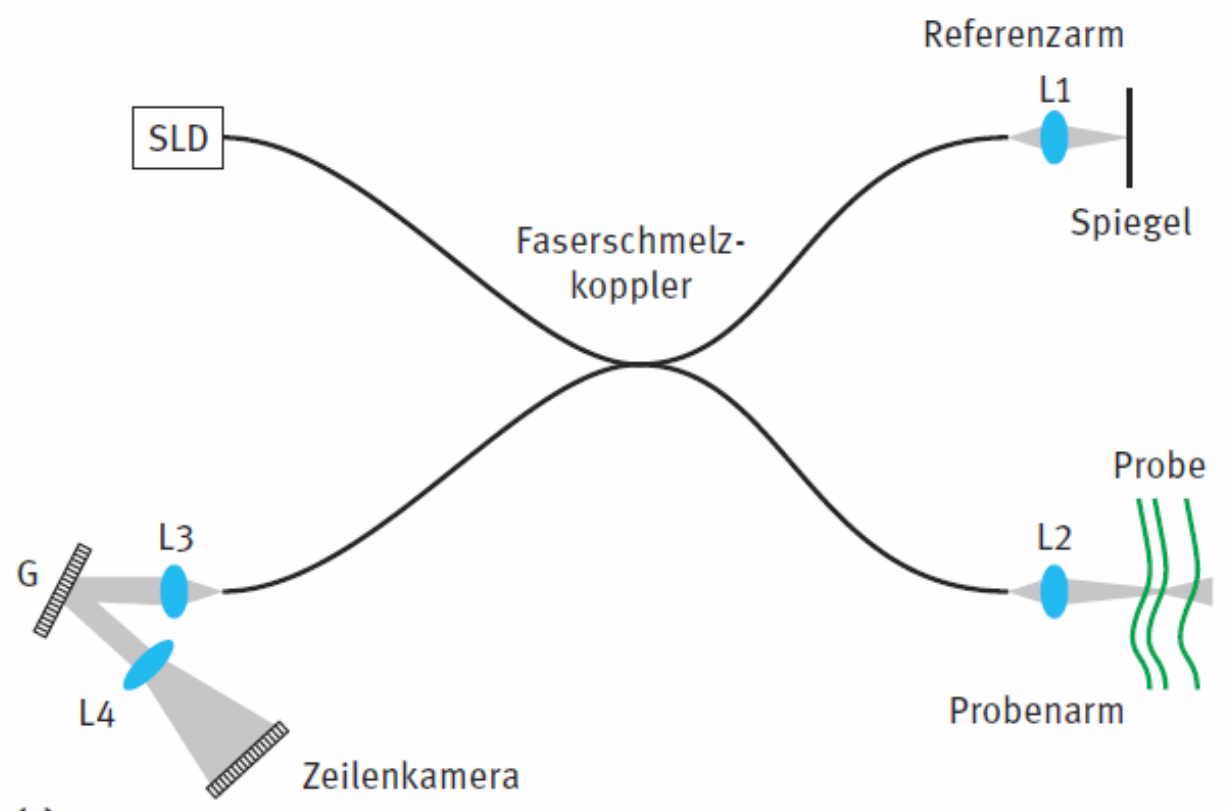

(a)

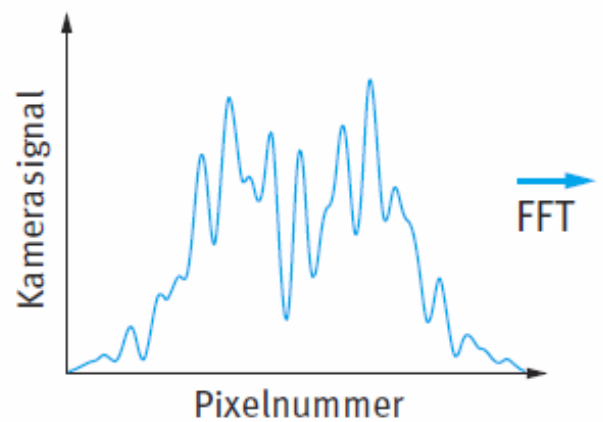

(b)



Abb. 1: Funktionsprinizip der optischen Kohärenztomografie (a), schematische Darstellung der Fourier-Transformation (FFT) (b), SLD: Superlumineszenzdioden, L1...L4: verschiedene Linsensysteme, G: Gitter (aus Biomedizinische Technik Band 7 - Medizinische Bildgebung, Seite 471 - 504, 2014) 


\section{Anwendung}

Das Prinzip der optischen Kohärenztomografie ist in der Medizin noch nicht weit verbreitet und findet hauptsächlich Anwendung in der Ophthalmologie. Dabei ist es möglich, die Netzhaut non-invasiv in vivo abzubilden und retinale Mikrostrukturen bzw. deren krankhafte Veränderungen im Schnittbild darzustellen und hochaufgelöst zu analysieren. Dies erlaubt die Diagnosestellung, Früherkennung und das Monitoring von verschiedenen Augenerkrankungen in Echtzeit, wie z.B. der Makuladegeneration oder verschiedenen Formen der Retinopathie [39]. Weitere Einsatzgebiete sind unter anderem die Dermatologie und Kardiologie $[40,41]$.

Die Darstellung oraler Strukturen wurde erstmals 1998 beschrieben $[36,42]$. Schon damals prognostizierten die Autoren die Möglichkeit der Beurteilung von Zahnhartsubstanzen und Detektion kariöser Läsionen, sowie der Bewertung von Restaurationen oder die Unterstützung der Diagnostik parodontaler Erkrankungen mithilfe der optischen Kohärenztomografie. Seither erfolgten diverse weitere Untersuchungen, die sich mit der Kariesdetektion, Remineralisation bzw. der Analyse des adhäsiven Verbundes zwischen Zahn und Restauration beschäftigten $[32,33,43,44]$. Vor allem beim Einsatz in klinischen Studien zur Bewertung von Adhäsivsystemen scheint die OCT ein großes Potential aufzuweisen, da bereits unmittelbar nach Füllungslegung bzw. sechs bis 12 Monate vor dem ersten Auftreten klinischer Auffälligkeiten, Defekte im adhäsiven Verbund tomografisch nachgewiesen werden können [17]. 


\subsection{Zielsetzung und Fragestellung}

In der vorliegenden Studie wurde folgende Zielstellung definiert:

In vivo sollen im Zeitraum von 12 Monaten Kompositfüllungen mit dem Universaladhäsiv Scotchbond Universal in zwei Konditionierungsmodi an nichtkariösen Zahnhalsläsionen einerseits klinisch und andererseits mit optischer Kohärenztomografie beurteilt und mit dem Referenzadhäsiv Optibond FL verglichen werden.

Hypothesen:

- Klinisch resultiert bei Verwendung von Scotchbond Universal in den Konditionierungsmodi self-etch und selective-enamel-etch eine geringere kumulative Fehlerrate als bei Verwendung von Optibond FL.

- Interfaziale adhäsive Defekte nehmen in allen Gruppen mit der Zeit zu.

- Mithilfe der OCT können bereits vermehrt adhäsive Defekte detektiert werden, bevor es klinisch zu marginalen Imperfektionen oder Füllungsverlusten kommt. 


\section{Publikationsmanuskript}

Haak, Rainer*; Hähnel, Marcus*; Schneider, Hartmut; Rosolowski, Maciej; Park, Kyung-Jin; Ziebolz, Dirk; Häfer, Matthias

Clinical and OCT outcomes of a universal adhesive in a randomized clinical trial after 12 months

Journal of Dentistry, Volume 90, November 2019, 103200

DOI: 10.1016/j.jdent.2019.103200

*These authors contributed equally to this study.

Journal Impact Factor (Stand bei Veröffentlichung): 3,280

Rang 2018 (Dentistry, Oral Surgery \& Medicine): 9/91 


\title{
Clinical and OCT outcomes of a universal adhesive in a randomized clinical trial after 12 months
}

\author{
Rainer Haak $^{\mathrm{a}, *, 1}$, Marcus Hähnel ${ }^{\mathrm{a}, 1}$, Hartmut Schneider ${ }^{\mathrm{a}}$, Maciej Rosolowski ${ }^{\mathrm{b}}$, Kyung-Jin Park ${ }^{\mathrm{a}}$, \\ Dirk Ziebolz ${ }^{\mathrm{a}}$, Matthias Häfer ${ }^{\mathrm{a}}$ \\ a Department of Cariology, Endodontology and Periodontology, University of Leipzig, Liebigstraße 12, 04103 Leipzig, Germany \\ ${ }^{\mathrm{b}}$ Institute for Medical Informatics, Statistics and Epidemiology (IMISE), Härtelstraße 16-18, 04107 Leipzig, University of Leipzig, Germany
}

\section{A R T I C L E I N F O}

\section{Keywords:}

Randomized clinical trial

Non-carious cervical lesion

Universal adhesive

FDI criteria

Tooth-composite bond failure

Optical coherence tomography

\begin{abstract}
A B S T R A C T
Objectives: To assess the performance of a universal adhesive in different application modes in non-carious cervical lesions clinically and by optical coherence tomography (OCT).

Methods: 55 adult patients with three non-carious cervical lesions (NCCL) each participated in the study. Lesions were restored with Scotchbond ${ }^{\mathrm{TM}}$ Universal (SBU, $3 \mathrm{M}$ ) applied in the self-etch (SBU-SE) and the selective-enamel-etch mode (SBU-SEE) in combination with Filtek ${ }^{\mathrm{TM}}$ Supreme XTE (3 M). OptiBond ${ }^{\mathrm{TM}}$ FL (OFL, Kerr) was used as a control. Restorations were clinically assessed (FDI criteria) after 14 days, 6 and 12 months and in parallel imaged by OCT (interfacial adhesive defects), starting immediately after filling placement. Cumulative failure rates (CFR) and means of interfacial adhesive defect were statistically evaluated.

Results: After 12 months, CFRs were lower in the SBU groups $(0.0 \%$ each) than in the OFL group (20.0\%, $\mathrm{p}=0.001$ ). Clinically, small marginal fractures occurred three times more often in the SBU-SE than in the SBUSEE group $(p=0.001)$. Immediately after filling placement and at each reassessment OCT revealed more interfacial defects at enamel interfaces for SBU/SE compared to SBU/SEE and OFL $\left(p_{i} \leq 0.044\right)$. At dentin/cement more defects were seen with OFL compared to SBU/SE and SBU/SEE $\left(\mathrm{p}_{\mathrm{i}} \leq 0.001\right)$. Before restoration loss, more interfacial defects appeared compared to remaining restorations $\left(\mathrm{p}_{\text {immediately } / 6 \mathrm{M}}=0.132 / 0.002\right.$ ).

Conclusions: Clinical evaluation and OCT imaging revealed higher interfacial integrity for SBU in both application modes compared to OFL. OCT detected interfacial bond failures prior to clinical deterioration or restoration loss.

Clinical significance: Scotchbond Universal showed an equivalent or improved bonding performance compared to the reference adhesive. Selective enamel etching is recommended. The parameter interfacial adhesive defect seems to be a valuable predictor for evaluation of adhesive restoration systems.
\end{abstract}

\section{Introduction}

During the last two decades, self-etching adhesive systems (SEA) became increasingly popular because of their alleged handling convenience and their expected lower susceptibility to errors. By introducing mild SEAs, a definite improvement in bonding effectiveness was noticed for the all-in-one adhesives so that more recent versions are almost competitive with proven multi-step golden standard approaches. [1] In order to create a sufficient retentive etching pattern at enamel an additional selective phosphoric-acid etching of the enamel cavity margins (SEE) is highly recommended [2-4] This was confirmed experimentally by increased enamel bond strength when a SEA was applied after enamel etching [5] as well as clinically with better marginal integrity and absence of marginal discoloration $[6,7]$

Since 2011, one-step self-etching systems with revised chemical compositions, the so-called multi-mode or universal adhesives (UA) were introduced into the market. According to the stated claim of manufacturers, these adhesives should be rather robust on wet and dry dentin and are indicated for use in the self-etch mode (SE) as well as in the etch-and-rinse mode (ER). Most of UA systems contain 10-MDP

\footnotetext{
* Corresponding author.

E-mail addresses: rainer.haak@medizin.uni-leipzig.de (R. Haak), marcus.haehnel@medizin.uni-leipzig.de (M. Hähnel), hartmut.schneider@medizin.uni-leipzig.de (H. Schneider), maciej.rosolowski@medizin.uni-leipzig.de (M. Rosolowski), kyung-jin.park@medizin.uni-leipzig.de (K.-J. Park),dirk.ziebolz@medizin.uni-leipzig.de (D. Ziebolz), matthias.haefer@medizin.uni-leipzig.de (M. Häfer).

${ }^{1}$ These authors contributed equally to this study.
} 
(methacryloyloxydecyl dihydrogen phosphate) [8].This functional monomer with a high etching potential [9] allows its application without a separate etching step, producing an effective ionic bond to hydroxyapatite through nano-layering $[10,11]$. In vitro, it has been proven that the bonding performance of UA to dentin was competitive regardless of the used application mode [12], which is also reflected by $\mu$ TBS to dentin [13]. Good study results have been reported most frequently for Scotchbond Universal, which was the first marketed UA [14]. At enamel, analogous to the SEAs, additional conditioning with phosphoric acid (selective enamel etch, SEE) has been recommended for UAs $[11,13,15,16]$. As a consequence, the current study design focused on the self-etch compared to the selective-enamel-etch approach.

Assessments of adhesive systems vary between numerous in-vitro techniques, which are often invasive [17] and clinical trials, which primarily use clinical success criteria $[3,18,19]$ partly combined with quantitative marginal analysis [20]. However, it remains controversial, how the results of these investigations should be discussed in relation to each other.

In one meta-analysis "some clear indications" have been advanced for a correlation of laboratory bond strength with clinical retention rates especially in Class-V restorations [21]. Further studies have described that $\mu$ TBS data of adhesive systems, especially after water storage for six months, showed a "good correlation" with clinical marginal discoloration of Class V restorations at least in the short-term [22]. Thermomechanical loading in combination with long-term water storage has been found useful in forecasting the durability of the resindentin bond created in vivo [23] and a reduced interaction of the resin to enamel found by SEM corresponded to a decreased marginal integrity in vivo [24]. By contrast, in another meta-analysis "only a moderate correlation" between microtensile and macrotensile bond strength results and marginal discoloration was demonstrated, and "no correlation" between these in vitro tests and retention loss or marginal integrity in vivo was shown [25]. These contradictory statements suggest that the parameters used for simulating bond degradation in laboratory settings are generally not directly transferable to clinical outcomes. Therefore, the concern remains to identify parameters that may be used to forecast the effectiveness [19] and durability [23] of adhesive bonds.

Clinically the question arises, what are suitable evaluation parameters that reliable address differences between adhesive-composite restoration systems over years of function? Besides others [26] the authors of this study identified three key parameters in their previous clinical trials: retention (and fractures), marginal adaptation (MA) and marginal staining (MS). The integrity of the tooth-composite interface can be assumed as the most crucial factor determining the clinical success of composite restorations. In light of the above, the initial and the tooth-composite bond manifesting in the further course should indicate the clinical performance of restoration systems. In principle, the quantitative marginal analysis appears suitable for this question, particularly the assessment of the marginal integrity using morphological criteria like margin gap or perfect margin [20]. However, the SEM analysis is only able to assess the margins of restorations in a complex and time-consuming process.

Furthermore, there is evidence that interfacial adhesive defects existing immediately after composite restoration might substantially interfere with the clinical success of the restoration [19]. Against this background, a reliable in vivo evaluation of the tooth-composite bond integrity would be desirable starting immediately after filling. In the authors' opinion, optical coherence tomography (OCT) could provide this.

OCT is a non-destructive, non-invasive imaging method with spatial resolution in the micron range that is routinely used in ophthalmology for retina assessment and is now attracting more attention in dental research to image surface structures up to a depth of 2-2.5 $\mathrm{mm}$ [27-29]. Parallel to the clinical evaluation, OCT proved to be appropriate for the assessment of marginal gaps and internal interfacial adhesive defects as parameters characterizing the integrity of the tooth-composite interface $[19,29]$. Also, the clinical relevance of an assessment of the toothcomposite bond using quantitative margin analysis, in combination with a clinical study after 90 months, was shown [20]. The clinical performance was in accordance with the quality of the restoration margins based on SEM and OCT.

The aim of this randomized clinical study was to assess the 12month performance of the universal adhesive Scotchbond ${ }^{\mathrm{TM}}$ Universal (SBU, 3 M Oral Care, St Paul, MN, USA) clinically and by OCT when placed in NCCLs in two application modes compared to a 3-step etchand-rinse control adhesive, which is a widely accepted gold standard for dental adhesives. We tested the hypotheses that (1) SBU shows a lower cumulative failure rate (CFR) using the self-etch or selectiveenamel etch application compared to a reference 3-step ER-adhesive, (2) interfacial adhesive defects demonstrated by OCT progress over time, and (3) OCT would show an increase of interfacial defects before detectable clinical deterioration or restoration loss.

\section{Materials and methods}

\subsection{Study design}

The randomized controlled clinical trial was approved by the local Ethics Committee with reference number 196-14-14042014 and was registered at German Clinical Trials Register \#DRKS00011084 (http:// www.drks.de/DRKS00011084). The study was double-blinded. The patients, the investigator (clinical assessment and OCT imaging) as well as the subsequent data evaluators were blinded with regard to the treatment modality of the participants. All adult participants were informed about the study and signed the informed consent. Three noncarious cervical lesions (NCCL) per patient were restored following a three-arm parallel design by one calibrated dentist of the department not further involved in this trial.

\subsection{Study population}

The current study included 55 patients aged between 43 and 84 years (mean $65 \pm 20.5$ ). This significantly exceeds the recommended minimum number of 30 restorations per study [30]. In a former clinical OCT study, it was shown that the performance of adhesive systems could be differentiated with a test power of $80 \%$ if a number of 18 pairs of restorations (pairwise comparison) is included [20]. All participants required three restorations of NCCL in incisors, canines or premolars. Criteria for inclusion were a positive pulp status $\left(\mathrm{CO}_{2}\right.$-snow) of the trial teeth and a physiological occlusal relationship with natural dentition. Patients were excluded if they had less than 20 teeth, any removable dentures, if contamination control during restoration was impossible to realize, and if a lesion communicated with pre-existing restorations. Moreover, periodontal probing depth above $4 \mathrm{~mm}$ at the trial teeth, alcohol and drug-dependence, pregnancy, habits and known allergies to materials used led to exclusion. The study focused on subjects with physiological chewing function without habits or massive abrasion facets on the study relevant teeth. Therefore, persons in treatment or wearing a hard plastic mouthguard were excluded. Both inclusion and exclusion were performed by the dentist who placed the restorations. The principal investigator enrolled the suitability of the study participants and created an group allocation of the lesions by a computergenerated list of random numbers.

\subsection{Restorative procedure}

The universal adhesive Scotchbond ${ }^{\mathrm{TM}}$ Universal ( $3 \mathrm{M}$ Oral Care, St Paul, MN, USA) was applied in the conditioning modes self-etch and selective-enamel-etch. The adhesive system Optibond ${ }^{\mathrm{TM}} \mathrm{FL}$ (Kerr $\mathrm{GmbH}$, Rastatt, Germany) served as the reference standard (ER mode). All lesion were restored with the nanocomposite Filtek ${ }^{\mathrm{TM}}$ Supreme XTE (3 M 
Table 1

Randomized allocation of teeth and lesions.

\begin{tabular}{|c|c|c|c|}
\hline & \multicolumn{2}{|c|}{ Number of restorations, $\mathrm{n}$} & \multirow[b]{2}{*}{ Optibond FL } \\
\hline & \multicolumn{2}{|c|}{ Scotchbond Universal } & \\
\hline & Self-etch mode & $\begin{array}{l}\text { Selective-enamel } \\
\text { mode }\end{array}$ & $\begin{array}{l}\text { Etch-and-rinse } \\
\text { mode }\end{array}$ \\
\hline & Filtek Supreme & Filtek Supreme & Filtek Supreme \\
\hline & XTE & XTE & XTE \\
\hline \multicolumn{4}{|l|}{ Location } \\
\hline$\bullet$ maxilla & 29 & 31 & 30 \\
\hline •mandible & 26 & 24 & 25 \\
\hline \multicolumn{4}{|l|}{ Lesion borderline } \\
\hline •enamel & - & - & - \\
\hline •dentin & 9 & 6 & 6 \\
\hline $\begin{array}{l}\cdot \text { mixed (enamel/ } \\
\text { dentin) }\end{array}$ & 46 & 49 & 49 \\
\hline \multicolumn{4}{|l|}{ Lesion depth } \\
\hline $\begin{array}{l}\text {-shallow ( }<1 \mathrm{~mm} \\
\text { deep) }\end{array}$ & 10 & 6 & 5 \\
\hline $\begin{array}{l}\text {-medium }(1-2 \mathrm{~mm} \\
\text { deep })\end{array}$ & 42 & 46 & 47 \\
\hline$\cdot \operatorname{deep}(>2 \mathrm{~mm}$ deep $)$ & 3 & 3 & 3 \\
\hline
\end{tabular}

Oral Care, Seefeld, Germany).

The sizes of the 165 lesions were assessed before restoration placement and varied from shallow (depth $\leq 1 \mathrm{~mm}$ ) and medium (depth $\leq 2 \mathrm{~mm}$ ) to deep (depth $>2 \mathrm{~mm}$ ) equivalent to scores 2 to 4 on Smith and Knight's tooth wear index [31]. The characteristics of the teeth and lesions are shown in Table 1. The calibrated operator (P.S.) restored all teeth after placement of 12 NCCL restorations in vitro under the supervision of the primary investigator.

All restorations were placed according to the following protocol using magnifying glasses (2.5x). Lesions and surrounding tooth surfaces were cleaned with an oil-and fluoride-free cleaning paste before shade selection. After application of a retraction cord (Ultrapak, Ultradent Products, Inc., South Jordan, USA) to expose the cervical cavity margins, the hypermineralised dentin and the enamel margins were carefully roughened using a $15 \mu \mathrm{m}$ diamond bur (Intensiv SA, Grancia, Switzerland). Contamination control, the adhesives and the filling material were applied according to manufacturer instructions (Table 2). Finally, the restorations were finished with fine-grained diamond burs $(15 \mu \mathrm{m})$ and polished with rubber points (Shofu Dental GmbH, Ratingen, Germany).

\subsection{Study outcomes}

\subsubsection{Clinical}

All study teeth were photographed prior to restoration, after restoration and at each follow-up. After 14 days (baseline, $\left.t_{1}\right), 6\left(t_{2}\right)$ and after 12 months $\left(t_{3}\right)$ the principal investigator (M.H.) clinically evaluated the restorations according to the FDI criteria [32]. The aesthetic, functional and biological criteria were assessed visually with magnifying glasses (2.5x), by using explorers (Kit-EX: tip diameter $150 \mathrm{~mm}$, $250 \mathrm{~mm}$; Deppeler SA, Rolle, Switzerland), by interviewing, by $\mathrm{CO}_{2}-$ snow, by use of a visual analogue scale and by a periodontal probe (P15/11.5B6; Hu-Friedy Mfg. B.V., Rotterdam/Netherlands). Scoring ranges from 1 (very good), 2 (good, after correction very good), 3 (sufficient/satisfactory, minor shortcomings), 4 (unsatisfactory, but repairable), 5 (poor, replacement necessary) [32]. At baseline, isolated small marginal fractures which occurred in the first two weeks after filling were removed until marginal adaptation could be assessed with score 1 . If restorations were rated clinically unacceptable in one of the criteria, they had to be excluded from further assessment and were repaired or replaced. The clinical endpoint includes the parameters fractures and retention, marginal adaptation (MA) and marginal staining (MS).

\subsubsection{OCT imaging}

In contrast to the clinical assessment which started at baseline, OCT assessment began immediately after filling placement (initially) and parallel to the clinical examination at 6 and 12 months. All restorations were 3D imaged using the spectral domain optical coherence tomography (SD-OCT, Telesto II; Thorlabs GmbH, Dachau, Germany). The principal investigator (M.H.) performed both the clinical assessment as well as the OCT imaging. The Telesto II used a superluminescent diode of center wavelength $1310 \mathrm{~nm}( \pm 120 \mathrm{~nm})$. The axial/lateral resolution was verified by $<7.5$ (air) $\mu \mathrm{m} / 15 \mu \mathrm{m}$. Further technical specifications were: field of view and depth maximum $10 \mathrm{~mm} \times 10 \mathrm{~mm} \times$ $3.5 \mathrm{~mm}$ (air, pixels maximum $1000 \times 500 \times 1024$ ), imaging speed $76 \mathrm{kHz}$, sensitivity $\leq 106 \mathrm{~dB}$ and A-scan average 1 .

In the present conception, the OCT-system allowed the imaging of vestibular surfaces of anterior teeth and premolars. The stabilized imaging probe was positioned almost at a right angle, 30 to $35 \mathrm{~mm}$ from the restoration surface.

The image analysis was carried out as previously described [19]. The examiner (M.H.2) was trained and calibrated by an experienced OCT operator (P.S.). Out of the 350-400 B-scans per image stack, 25 equidistantly distributed images were used for the analysis (ImageJ $1.51 \mathrm{~s}$, National Institute of Health, USA). The tooth-composite interfaces at enamel, dentin and root cement were separately evaluated by manual tracking the lengths of the specific interface and the existing adhesive defect, represented by a white line (signal), using ImageJ (ImageJ $1.51 \mathrm{~s}$ ) [19]. The parameter "adhesive defect" was calculated for each B-scan in the following manner: length defect signal/length specific interface $\mathrm{x} 100, \%$. The weighted mean per group was calculated for enamel, dentin, and cement. Because of the minor percentage $(2 \%)$ of the cement-composite interface compared to dentin, data of both interfaces were merged in the final calculations.

\subsection{Statistical analysis}

\subsubsection{Clinic assessment}

At each recall, the cumulative failure rates (CFR) were calculated as follows for each criterion and for the sum of all criteria (total score) [32]: failure percentage $=[$ (Fprevious + Fcurrent) $/$ (Fprevious + Ncurrent)] x 100. Fprevious represents the number of previous failures before the current recall examination, Fcurrent and Ncurrent represent the number of failures and the number of restorations seen in the current recall [30]. Kaplan-Meier survival curves were calculated.

McNemar test was used to prove the differences for all parameters between groups per time (horizontal testing) and within each group over time (vertical testing). The statistical analysis was performed using SPSS Statistics for Windows 23.0 (IBM Corp. Armonk, NY, USA) using McNemar test (two-sided, $\alpha=0.05$ ).

\subsubsection{Interfacial bond failure (OCT)}

The weighted mean values of "adhesive defects" per group and time were calculated. In the case of restoration loss, the missing value was imputed from the highest value according to the respective group (missing data imputation). As the values were not generally normal distributed (Shapiro-Wilk-, Kolmogorov-Smirnov-test), the comparison between groups per time and within groups over time was based on non-parametric Friedman- and Wilcoxon-test (dependent samples). In a group with multiple retention loss, for all points in time before retention losses, the difference of bond failure was calculated between remaining and lost restorations using Kruskal-Wallis and Mann-WhitneyU-test as well as by regression analysis (mixed model). Due to the exploratory nature of this research, we generally refrained from correction for multiple testing and used raw $\mathrm{p}$-values for assessing the group differences at the level of significance $\alpha=0.05$.

For testing interpersonal reproducibility, ten restorations were randomly selected and assessed by two raters (dentin/cement-composite interface). For parameter "weighted mean of adhesive defect" rater 


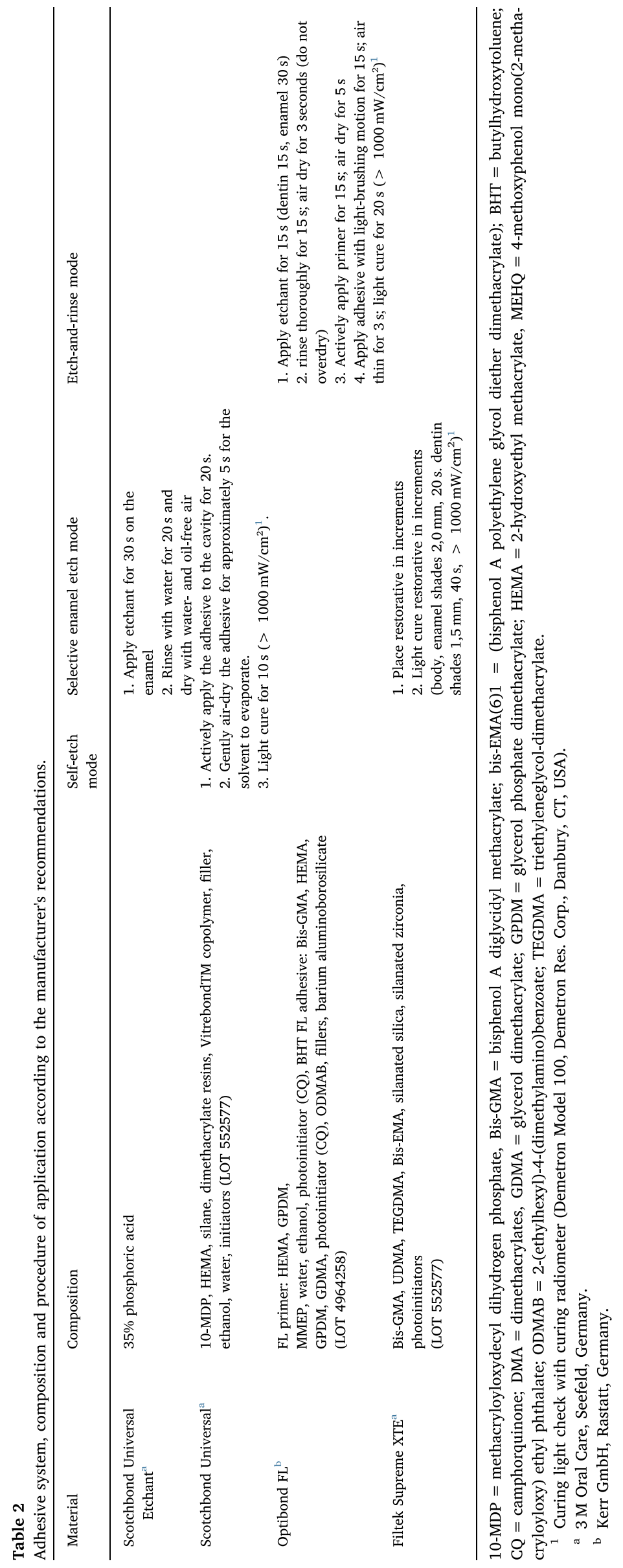




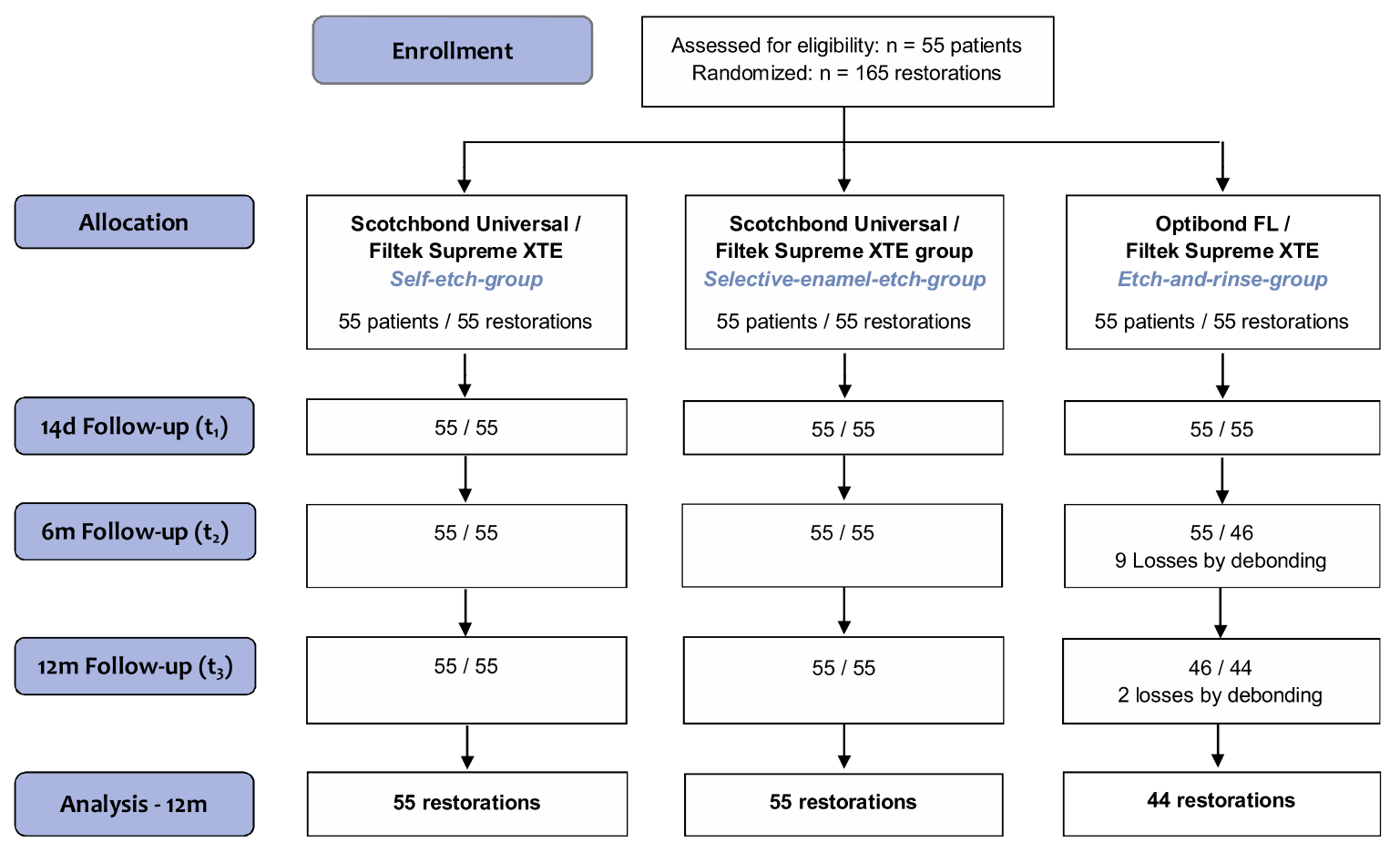

Fig. 1. CONSORT flow diagram.

2 showed a systematic deviation of $-27.4 \%$ compared to rater 1 . In determining significant group differences, there was $100 \%$ agreement between the two raters (12 comparisons, Wilcoxon-test). The intrapersonal testing was done by three assessments at three randomly selected restorations each ( $25 \mathrm{~B}$-scans), separately for the enamel- and dentin/cement-composite interface. The mean standard errors were $4.9 \%$ (enamel) or $3.9 \%$ (dentin/cement).

\section{Results}

\subsection{Clinical assessment}

After 12 months, 154 out of 165 restorations were evaluated (Fig. 1). For each recall $\left(t_{1}, t_{2}\right.$ and $\left.t_{3}\right)$ the reassessment rates, aesthetic, functional and biological criteria, and CFRs from baseline to 12-month recall are summarized in Table 3. The p-values for CFR (fractures/retention score 5, as a result of retention loss), for MS, MA and corresponding to the differences between groups at each time (cross-sectional testing) and per group over the entire assessment period (longitudinal testing) are summarized in Tables $4 \mathrm{a}$ and $4 \mathrm{~b}$.

All failures resulting from a partial or total retention loss occurred in the OFL group and significantly increased after both 6 and 12 months compared to SBU-SE and SBU-SEE (Tables 3, 4a). Over time, in both SBU groups, no restoration was lost, and all restorations were scored as 1 or 2 for all parameters. In the OFL group, nine restorations were lost after six months, increased to 11 restoration losses after 12 months, resulting in an overall CFR of $20.0 \%$ (Tables 3, 4a). Cumulative survival rates were calculated (Fig. 2). After 6 and 12 months, the Kaplan-Meier curves significantly differ between each of the two SBU groups and the OFL group.

After six months there were no significant group differences for marginal staining and marginal adaptation (Table 4a). After 12 months MS significantly increased, and MA decreased in the SBU-SE group compared to SBU-SEE. In the OFL group, MS score 2 appeared more often compared to SBU-SEE, which was not the case compared to SBUSE. MA showed no significant differences between the OFL and the SBU groups.

The restorations of all groups showed progressive marginal deterioration up to score 2, which corresponds to clinical acceptance. $23.6 \%$ of the restorations in the SBU-SE group showed a significant increased MS after 12 months compared to baseline, $43.6 \%$ showed a significant decreased MA. In the SBU-SEE group, the number of restorations with an MS rating of score 2 remained stable at a low level of $1.8 \%$, while the number of restorations with MA score 2 increased to $14.5 \%$ (Table 4a).

Table 3

Clinical quality of the restorations from baseline to 12 months.

\begin{tabular}{|c|c|c|c|c|c|c|c|c|c|}
\hline & \multicolumn{3}{|c|}{ SBU-SE } & \multicolumn{3}{|c|}{ SBU-SEE } & \multicolumn{3}{|l|}{ OFL } \\
\hline & \multicolumn{3}{|c|}{$\mathrm{BL} / 6 \mathrm{mo} / 12 \mathrm{mo}$} & BL & $6 \mathrm{mo}$ & $12 \mathrm{mo}$ & $\mathrm{BL}$ & $6 \mathrm{mo}$ & $12 \mathrm{mo}$ \\
\hline Patients, restorations (n) & \multicolumn{3}{|l|}{55} & 55 & 55 & 55 & 55 & 55 & 46 \\
\hline Reassessment rate (\%) & \multicolumn{3}{|l|}{100} & 100 & 100 & 100 & 100 & 100 & 100 \\
\hline Acceptable, \% & 100 & 100 & 100 & 100 & 100 & 100 & 100 & 100 & 100 \\
\hline Non acceptable, $\%$ & 0.0 & 0.0 & 0.0 & 0.0 & 0.0 & 0.0 & 0.0 & 0.0 & 0.0 \\
\hline Acceptable, \% (fractures/retention) & 100 & 100 & 100 & 100 & 100 & 100 & 100 & 83.6 & 80.0 \\
\hline Non acceptable, $\%$ & 0.0 & 0.0 & 0.0 & 0.0 & 0.0 & 0.0 & 0.0 & $16.4^{3}$ & $20.0^{3}$ \\
\hline Acceptable, \% & 100 & 100 & 100 & 100 & 100 & 100 & 100 & 100 & 100 \\
\hline Non acceptable, \% & 0.0 & 0.0 & 0.0 & 0.0 & 0.0 & 0.0 & 0.0 & 0.0 & 0.0 \\
\hline Acceptable, \% & 100 & 100 & 100 & 100 & 100 & 100 & 100 & 83.6 & 80.0 \\
\hline Non acceptable, $\%$ & 0.0 & 0.0 & 0.0 & 0.0 & 0.0 & 0.0 & 0.0 & $16.4^{3}$ & $20.0^{3}$ \\
\hline
\end{tabular}

${ }^{1}$ cumulative over time, ${ }^{2}$ cumulative all criteria, ${ }^{3}$ exclusively caused by retention loss. 
Table 4a

Marginal staining, marginal adaptation (score 2) and fractures/retention (score 5). Group differences ( $\left.p_{i}\right)$ at 6 and 12 months.

\begin{tabular}{|c|c|c|c|c|c|c|c|}
\hline & & \multicolumn{2}{|c|}{ Marginal staining score 2} & \multicolumn{2}{|c|}{ Marginal adaptation score 2} & \multicolumn{2}{|c|}{ Fractures/retention score $5^{2}$} \\
\hline & & 6 months & 12 months & 6 months & 12 months & 6 months & 12 months \\
\hline \multirow[t]{2}{*}{ SBU-SE vs. SBU-SEE } & $\%$ & $14.5 / 3.6$ & $23.6 / 1.8$ & $21.8 / 5.5$ & $43.6 / 14.5$ & $0.0 / 0.0$ & $0.0 / 0.0$ \\
\hline & $\mathrm{p}_{\mathrm{i}}$ & 0.109 & 0.002 & 0.125 & 0.001 & n. c. & n. c. \\
\hline \multirow[t]{2}{*}{ SBU-SE vs. OFL } & $\%$ & $14.5 / 17.4$ & $23.6 / 22.7$ & $21.8 / 17.4$ & $43.6 / 29.5$ & $0.0 / 16.4$ & $0.0 / 20.0$ \\
\hline & $\mathrm{p}_{\mathrm{i}}$ & 0.791 & 1.000 & 1.000 & 0.664 & 0.004 & 0.001 \\
\hline \multirow[t]{2}{*}{ SBU-SEE vs. OFL } & $\%$ & $3.6 / 17.4$ & $1.8 / 22.7$ & $5.5 / 17.4$ & $14.5 / 29.5$ & $0.0 / 16.4$ & $0.0 / 20.0$ \\
\hline & $\mathrm{p}_{\mathrm{i}}$ & $0.070^{1}$ & 0.004 & 0.125 & 0.146 & 0.004 & 0.001 \\
\hline
\end{tabular}

Bold: significant; ${ }^{1}$ trend; ${ }^{2}$ retention loss, representing the cumulative failure rate; $\mathrm{n} . \mathrm{c} .:$ not calculable (McNemar, 2 -sided).

In the OFL group, the MS score 2 increased significantly over time to $22.7 \%$ and the MA score $2-29.5 \%$ (Tables $4 \mathrm{a}$ and $4 \mathrm{~b}$ ).

\subsection{OCT assessment}

In Table 5 and Figs. 4, 5 the results of the OCT evaluation are presented. In all groups adhesive defects were verifiable at the enameland dentin/cement-composite interfaces, with group differences at each time (cross-sectional testing) and per group over the entire assessment period (longitudinal testing). The dentin/cement-composite interface predominated with a length share of $85.2 \%$ compared to enamel with $14.8 \%$.

Enamel-composite interface (Fig. 3, Table 6)

At each time, SBU-SE showed significantly more interfacial defects compared to the other groups. OFL revealed a significantly higher level of interfacial adhesive defects than SBU-SEE after six months. After 12 months, this difference has remained as a trend. Over time, defects increased in the SBU-SE group $\left(t_{0}-t_{2} / t_{3}, t_{2}-t_{3}\right)$, in group SBU-SEE $\left(t_{0}-\right.$ $\left.t_{3}, t_{2}-t_{3}\right)$ and with OFL $\left(t_{0}-t_{2} / t_{3}\right)$. Generally, the broadest distribution of the data could be observed in the SBU-SE group. There is a strong reproducibility in the group differences beginning with $t_{0}$ up to $t_{3}$.

Dentin/cement-composite interface (Fig. 4, Table 6)

Significantly less interfacial defects were observed in SBU-SEE compared to SBU-SE after 6 and 12 months. OFL showed more defects than the other groups immediately after filling placement and at 6 and 12 months $(p<0.001)$. Over time more defects appeared at $t_{3}$ compared to $t_{2}$ in all groups. SBU-SE and OFL showed increased defects after 12 months compared to $t_{0}$. Whereas OFL revealed more adhesive defects from $t_{0}$ to $t_{2} / t_{3}$, SBU-SEE showed fewer defects at $t_{2}$ compared to $t_{0}$. After 6 and 12 months, the broadest distribution of the data could be observed in the OFL group. Again, there is a strong reproducibility in the group differences beginning with $t_{0}$ up to $t_{3}$.

Based on these observations the following key results can be identified: SBU-SEE showed mostly less adhesive defects than SBU-SE regardless of the tooth substrate. Starting with six months, OFL revealed more defects in enamel compared to SBU-SEE and was inferior to both SBU groups at the dentin interface. In general, a progression of interfacial adhesive defects could be observed in each group over time, and the group differences for bond failures were highly reliable over time.



Fig. 2. Cumulative survival in the system comparison from baseline to 12 months.

(SBU - Scotchbond Universal, OFL - Optibond FL; SE - self-etch approach, SEE - selective enamel etch approach)

\subsection{Clinic and OCT}

The higher amount of adhesive defects at dentin interfaces (OCT) initially found in the OFL group was conforming to the higher clinical retention loss compared to SBU in both conditioning modes. Retention losses in the OFL group were clinically observed with a delay of 6 months after OCT detection of adhesive defects above average. After 12 months, this was confirmed with increased interfacial adhesive defects compared to SBU and further OFL retention losses. The progress of retention loss in this group was conforming to the steeper incline of the median compared to SBU. The higher amount of adhesive defects at six months in the SBU-SE group compared to SBU-SEE showed no clinical correlate (Fig. 4, Table 6). Starting with six months, at the enamelcomposite interface, more defects were observed in the OFL group than in the SBU-SEE group, which corresponded to the clinical outcome. The

Table 4b

Changes in marginal staining, marginal adaptation (score 2) and fractures/retention (score 5) per group from baseline up to 12 months ( $\mathrm{p}_{\mathrm{i}}$ ).

\begin{tabular}{|c|c|c|c|c|c|c|c|c|c|}
\hline & \multicolumn{3}{|c|}{ Marginal staining score 2} & \multicolumn{3}{|c|}{ Marginal adaptation score 2} & \multicolumn{3}{|c|}{ Fractures/retention score $5^{2}$} \\
\hline & BL vs. 6 mo & $6 \mathrm{mo}$ vs. $12 \mathrm{mo}$ & BL vs. $12 \mathrm{mo}$ & BL vs. $6 \mathrm{mo}$ & $6 \mathrm{mo}$ vs. $12 \mathrm{mo}$ & BL vs. $12 \mathrm{mo}$ & BL vs. 6 mo & $6 \mathrm{mo}$ vs. $12 \mathrm{mo}$ & BL vs. $12 \mathrm{mo}$ \\
\hline SBU-SE & 0.289 & 0.267 & 0.022 & $<0.001$ & $<0.023$ & $<0.001$ & n. c. & n. c. & n. c. \\
\hline SBU-SEE & 1.000 & 1.000 & 1.000 & 0.250 & 0.180 & 0.008 & n. c. & n. c. & n. c. \\
\hline OFL & 0.219 & 0.388 & 0.001 & 0.008 & $0.065^{1}$ & $<0.001$ & 0.004 & 0.500 & 0.001 \\
\hline
\end{tabular}

Bold: significant; ${ }^{1}$ trend; ${ }^{2}$ retention loss, representing the cumulative failure rate; n. c.: not calculable (McNemar, 2 -sided). 
Table 5

OCT assessment regarding to marginal staining (MS) and marginal adaptation (MA). Differences of adhesive defects score 2 minus score 1 (Diff. AD) at the toothcomposite interface after 6 and 12 months and comparison of adhesive defects between restorations of score 2 vs. score 1 ( $\mathrm{p}_{\mathrm{AD}}$ ).

\begin{tabular}{|c|c|c|c|c|c|c|c|c|c|c|}
\hline & \multicolumn{5}{|c|}{ Marginal staining score 2 vs. score 1} & \multicolumn{5}{|c|}{ Marginal adaptation score 2 vs. score 1} \\
\hline & \multicolumn{5}{|l|}{ Ост } & \multicolumn{5}{|l|}{ OCT } \\
\hline & & \multicolumn{2}{|l|}{ Enamel } & \multicolumn{2}{|c|}{ Dentin/cement } & & \multicolumn{2}{|l|}{ Enamel } & \multicolumn{2}{|c|}{ Dentin/cement } \\
\hline & & $6 \mathrm{M}$ & $12 \mathrm{M}$ & $6 \mathrm{M}$ & $12 \mathrm{M}$ & & $6 \mathrm{M}$ & $12 \mathrm{M}$ & $6 \mathrm{M}$ & $12 \mathrm{M}$ \\
\hline \multirow[t]{2}{*}{ SBU- SE } & Diff. $A D^{1}$ & -5.36 & +21.65 & +13.37 & +1.48 & Diff. $\mathrm{AD}^{1}$ & +10.26 & +24.84 & -1.28 & +0.39 \\
\hline & $\mathrm{p}_{\mathrm{AD}}$ & 0.616 & 0.097 & 0.005 & 0.973 & $\mathrm{p}_{\mathrm{AD}}$ & 0.988 & 0.003 & 0.909 & 0.397 \\
\hline \multirow[t]{2}{*}{ SBU- SEE } & Diff. $\mathrm{AD}^{1}$ & +9.05 & -2 & +13.07 & -11.25 & Diff. $\mathrm{AD}^{1}$ & +11.59 & +7.17 & +8.57 & -5.18 \\
\hline & $\mathrm{p}_{\mathrm{AD}}$ & 0.075 & $-{ }^{2}$ & 0.065 & 0.145 & $\mathrm{p}_{\mathrm{AD}}$ & 0.001 & 0.308 & 0.074 & 0.308 \\
\hline \multirow[t]{2}{*}{ OFL } & Diff. $\mathrm{AD}^{1}$ & -3.16 & -3.21 & +0.59 & -8.62 & Diff. $\mathrm{AD}^{1}$ & +0.40 & -3.87 & +4.87 & -11.12 \\
\hline & $\mathrm{p}_{\mathrm{AD}}$ & 0.976 & 0.257 & 0.447 & 0.527 & $\mathrm{p}_{\mathrm{AD}}$ & 0.265 & 0.075 & 0.967 & 0.427 \\
\hline
\end{tabular}

Bold: significant; ${ }^{1}$ differences of weighted mean values of adhesive defect (AD) for score 2 minus score $1 ;{ }^{2}$ score 2 no enamel interface .

initially increased amount of adhesive defects in the SBU-SE group compared to SBU-SEE and OFL was not identifiable clinically (Fig. 3, Table 6).

As retention loss was only observed for OFL, the relation to advancing interfacial adhesive defects could only be described for these restorations. At the dentin/cement-composite interface with $85.2 \%$ of total length, restorations that were lost after six months initially showed $27.3 \%$ interfacial adhesive defects compared to $19.6 \%$ on the remaining restorations $(\mathrm{p}=0.073$, trend). At restorations that were lost after 12 months, initially $25.2 \%$ more adhesive defects (not significant) were observed when compared to the restorations still in clinical use $(19.8 \%$, $\mathrm{p}=0.132)$. After six months this difference became significant $(77.1 \%$ vs. $32.6 \%, \mathrm{p}=0.002$ ) when only the fillings were considered that have been lost after 12 months.

While OCT cannot detect MS if it is not associated with marginal gap formation, MA is partially associated with marginal gap formation. The group differences (significant or trend) in both clinical parameters MS and MA in Tables 4a (in bold) were in total agreement with the differences of the adhesive defects between the three groups, both at the enamel and dentin/cement. Again, these differences appeared 6-12 months earlier than clinically (Figs. 4, 5; Table 6). In principle, this also applies to the non-significant but clinically distinct differences. Considering restorations with clinical scores 1 vs. 2 for MS and MA, after 12 months there was no relation with interfacial gap formation (Table 5).

\section{Discussion}

The clinical assessment of adhesive systems on NCCLs is state of the art. Additionally, in the present study, the adhesive interface of each restoration was imaged by optical coherence tomography (OCT) at each recall in addition to the clinical findings. This analysis provides a view on the presence and development of the interfacial adhesive defects starting immediately with the filling placement that can help to explain clinical outcomes, especially when considering the individual hard



Fig. 3. Interfacial adhesive defects (\%) at enamel-composite interface, immediately after filling placement $\left(t_{0}\right)$, after $6\left(t_{2}\right)$ and 12 months $\left(t_{3}\right)$. 


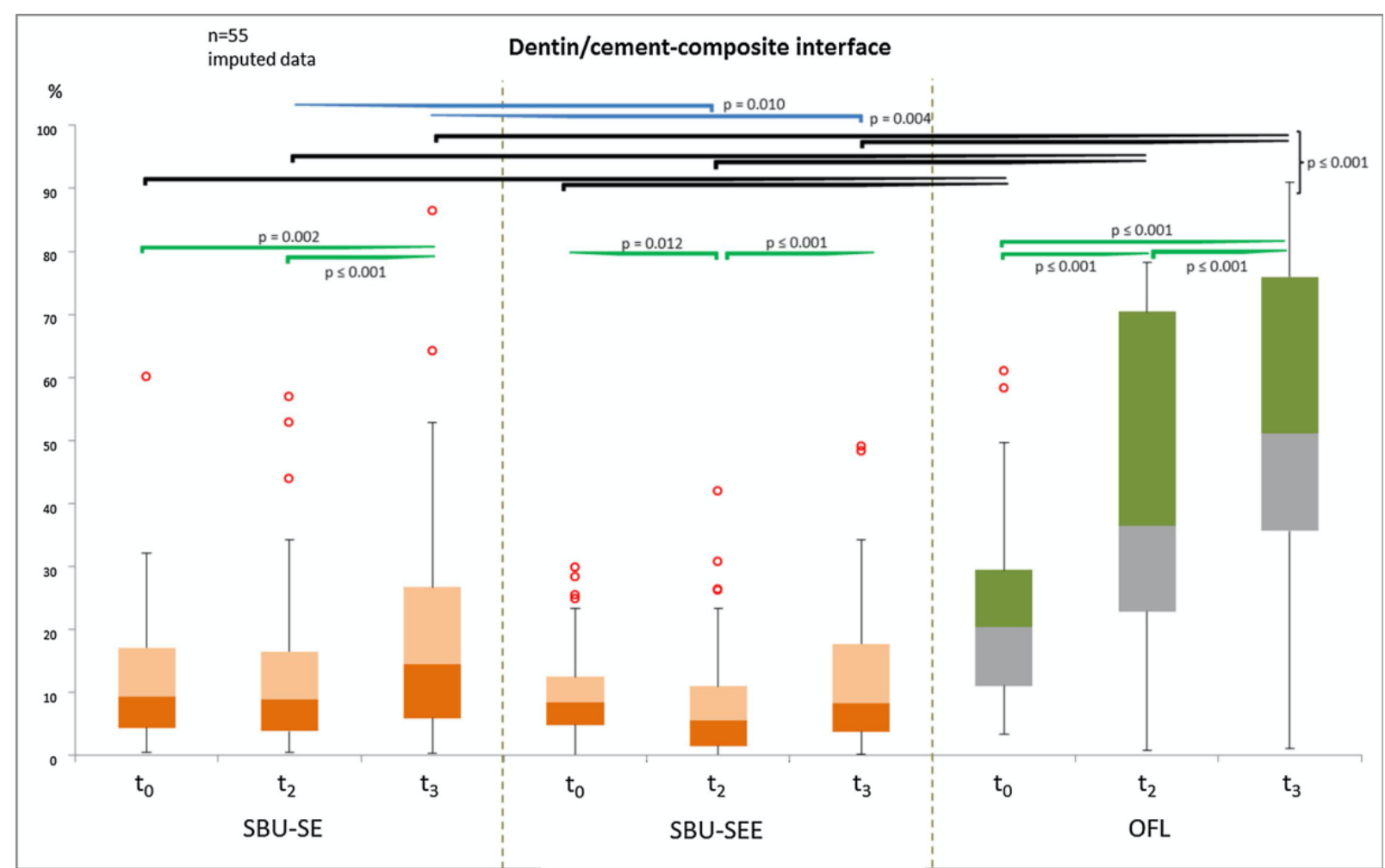

Fig. 4. Interfacial adhesive defects (\%) at dentin/cement-composite interface, immediately after filling placement $\left(\mathrm{t}_{0}\right)$, after $6\left(\mathrm{t}_{2}\right)$ and 12 months $\left(\mathrm{t}_{3}\right)$.

tooth substances. For the first time to our knowledge, we were able to show that before restoration deterioration became clinically detectable, adhesive defects were already visible with OCT.

After 12 months Scotchbond Universal either used in the SE or SEE mode showed a higher clinical retention rate compared to the 3-step reference system Optibond FL, which means that the first alternative hypothesis can be accepted. This result is supported by significantly more extended interfacial defects to dentin/cement (OCT) compared to SBU independent of its application mode. This effect was seen immediately after restoration and remained robust up for the whole observation period. Simultaneously, faster progress of adhesive defects to dentin was observed with OFL. In the SBU groups, no clinical differences were found, but in the group SBU-SE, more defects were found with OCT, which started for enamel with $\mathrm{t}_{0}$ and at dentin/cement with $t_{2}$. This phenomenon can be explained by the fact that clinical restorations with clinically acceptable margins often show internal debonding (Fig. 5).

Secondly, progression of interfacial defects could be confirmed in


Fig. 5. Example for clinical and OCT imaging at baseline (BL) and at 12-month recall (patient 33, tooth 33, Optibond FL, enamel/dentin/cement borderline); region of OCT B-scan (vertical blue line); BL: Clinic - marginal adaptation and staining score 1 each, OCT - initial interfacial gap at dentin/cement (white arrow). 12M: Clinic - marginal adaptation and staining score 2 each, OCT - extensive interfacial gap (white arrows). Co - composite, E - enamel, D - dentin, Ce - cement, G - gingiva (The reader is referred to the web version of this article for coloured clinical images). 
Table 6

Weighted mean values and standard deviation for "adhesive defect" up to 12 months.

\begin{tabular}{|c|c|c|c|c|c|c|}
\hline & \multicolumn{3}{|l|}{ Enamel } & \multicolumn{3}{|c|}{ Dentin/cement } \\
\hline & Initial & 6 months & 12 moths & Initial & 6 months & 12 months \\
\hline \multirow[t]{2}{*}{ SBU-SE } & $14.0^{\mathrm{a}, \mathrm{c}, \mathrm{i}, \mathrm{j} j}$ & $19.2^{\mathrm{a}, \mathrm{b}, \mathrm{k}, \mathrm{l}}$ & $28.2^{\mathrm{b}, \mathrm{c}, \mathrm{m}, \mathrm{n}}$ & $11.5^{\mathrm{p}, \mathrm{z}}$ & $12.6^{\mathrm{q}, \mathrm{w}, \mathrm{B}}$ & $19.0^{\mathrm{p}, \mathrm{q}, \mathrm{x}, \mathrm{D}}$ \\
\hline & \pm 14.6 & \pm 17.4 & \pm 23.2 & \pm 10.8 & \pm 13.3 & \pm 17.5 \\
\hline \multirow[t]{2}{*}{ SBU-SEE } & $3.7^{\mathrm{d}, \mathrm{i}}$ & $4.3^{\mathrm{e}, \mathrm{k}, \mathrm{o}}$ & $7.1^{\mathrm{d}, \mathrm{e}, \mathrm{m}}$ & $10.4^{\mathrm{r}, \mathrm{y}}$ & $9.1^{\mathrm{r}, \mathrm{s}, \mathrm{w}, \mathrm{A}}$ & $12.5^{s, \mathrm{x}, \mathrm{C}}$ \\
\hline & \pm 5.1 & \pm 4.9 & \pm 7.7 & \pm 7.2 & \pm 8.8 & \pm 11.1 \\
\hline \multirow{2}{*}{ OFL } & $3.4^{\mathrm{f}, \mathrm{g}, \mathrm{j}}$ & $7.7^{\mathrm{f}, \mathrm{h}, \mathrm{l}, \mathrm{o}}$ & $9.5^{\mathrm{g}, \mathrm{h}, \mathrm{n}}$ & $20.9^{t, v, y, z}$ & $41.7^{\mathrm{t}, \mathrm{u}, \mathrm{A}, \mathrm{B}}$ & $52.8^{\mathrm{u}, \mathrm{v}, \mathrm{C}, \mathrm{D}}$ \\
\hline & \pm 4.4 & \pm 13.8 & \pm 8.6 & \pm 14.0 & \pm 24.7 & \pm 26.2 \\
\hline
\end{tabular}

Vertical and horizontal comparison: same raised letters indicate significant group differences $\left(\mathrm{p}_{\mathrm{i}}<0.05\right)$.

the OCT images. In the groups SBU-SE and OFL at the enamel, interfacial defects progress over the entire 12 months, in the group SBU-SEE this effect began with the 6-month follow-up. At dentin/cement, in the OFL group, interfacial defects progressed over the whole study period, whereas in both SBU-groups initiation was seen at the 6-month followup.

Additionally, the third hypothesis can be accepted. OCT showed an increase of interfacial defects before detectable clinical deterioration or retention loss. However, not all increasing defects led to restoration loss within the 12-month observation period but even initially, restorations without interfacial adhesive defects were rarely seen. Defect formation mostly started already with restoration placement and increased at different speeds up to 12 months. An increase in defects was observed, especially at enamel in the SBU-SE group and at dentin/cement in the OFL group. On enamel, the increased values for adhesive defects in the SBU-SE and OFL group over the entire period were facing the increased clinical values for marginal adaptation and marginal staining. This came into effect with time delays: after 12 months for the cross-sectional comparison and after six months for longitudinal viewing. With OCT, a difference between SBU and OFL was observed at the dentincomposite interface immediately after filling application, thus earlier and with a shift of six months compared to the clinic.

The adhesive system under study Scotchbond Universal was proved in several prospective clinical trials on NCCLs. Irrespective of the bonding strategy applied, its clinical behavior was found to be acceptable at six months [33] as well as after 18 [34] and 36 months [35]. In a further 24 months in-vivo study, SBU was evaluated on NCCLs after preparation of a $0.5 \mathrm{~mm}$ bevel on the occlusal margin [36]. The etchand-rinse system Scotchbond Multi-purpose was used as a reference. A trend was shown towards increased restoration failure of the reference material compared to SBU both in the etch-and-rinse and self-etch mode $(p=0.06)$. This already suggested that SBU might be superior to classical etch-and-rinse systems.

Optibond FL was used as a control because this widely used etchand-rinse adhesive has been a reference standard for adhesive studies for years $[37,38]$. In line with other studies, it can also be considered as a reference for estimating clinical failure [37-40]. Further advantageous aspects of this selection are that etching with phosphoric acid still establishes the best and most stable adhesion to the enamel and that the technique sensitivity of a classical and proven etch-and-rinse adhesive could be evaluated compared to the universal adhesive. Against this background, it was surprising that this established control adhesive performed weaker compared to the test groups and to previous studies. In clinical studies on NCCL, the failure rates of Optibond FL groups varied from $0.0 \%$ [39] up to acceptable $4 \%$ after one year [40] and $9 \%$ after five [41]. In contrast, $20 \%$ of the OFL restorations were lost after 12 months in the present study. Currently, this apparent and unexpected discrepancy from previous studies cannot be explained and should be interpreted with caution. At this time, the authors assume that the formulation of Optibond FL has not changed compared to previous studies, as no relevant information is publicly available. It should also be noted that the adhesive was used in accordance with the manufacturer's recommendations and that the dentist had many years of experience with Optibond FL as the standard adhesive and was extensively calibrated prior to this study. For Optibond FL, a sufficient micro-retention pattern is decisive for adhesion to the tooth structures. We suspect that the dentin tubules and collagen network may not have been sufficiently exposed and that the adhesive could not penetrate sufficiently into the dentin surface. The steps that can be associated with this are mechanical conditioning and surface removal with the fine-grained diamonds and the duration of phosphoric acid application (15 s). One could speculate that a slightly more aggressive pretreatment of the dentin surface on the sclerotic dentin of the NCCLs could be more advantageous with Optibond FL.

Furthermore, the clinical results were supported by the significantly increased interfacial adhesive defects in the OCT images. In a recent in vitro study, OFL was not found to be statistically different after 12 months of water storage when compared to SBU regardless of the application mode [42]. One explanation of why the present results differ from in vitro bond strength studies on Optibond FL is based on the difference of the bonding substrate. Mostly, the dentin was freshly prepared prior to adhesive application $[43,44]$, whereas clinical studies often use NCCLs. It has to be taken into account that about $90 \%$ of the tooth tissue in NCCLs is sclerotic dentin characterized by partial or complete obliteration of the dentinal tubules and by the presence of sclerotic casts [45]. This hypermineralized surface layer affects the conditioning and hinders the monomer penetration and the resin hybridization process of the underlying dentin, making resin hybridization difficult [46]. For SEA the micro-retentive bonding to this substrate becomes very unpredictable and challenging [47]. $\mu$ TBS values were significantly lower than to non-sclerotic or prepared dentin, and thermocycling had a significantly negative effect on the long-term durability of the resin-dentin bond [48]. Without removal of the hypermineralized surface layer of dentin or the application of strong acids, the use of SEA on sclerotic dentin should not lead to a sufficient bond [49].

In a meta-analysis, it was shown, that tooth composite restorations placed on roughened dentin resulted in a higher retention rate compared to unprepared dentin [50]. In the present study, the sclerotic dentin was also slightly roughened with finishing diamond burs before the application of each adhesive. However, mechanical conditioning cannot be standardized, which could potentially be a source of bias in comparison between groups. As mentioned above, one could hypothesize that the significant restoration loss in the reference group might be due to insufficient mechanical and chemical conditioning of the sclerotic dentin. In contrast, it was proven for universal adhesives that dentin roughening before application did not affect the clinical behavior of composite restorations placed in NCCLs irrespective of the acid conditioning mode used [51], which could be an indication of lower susceptibility of universal adhesives to conditioning differences.

SBU contains 10-MDP (methacryloyloxydecyl dihydrogen phosphate) as a functional monomer that has been shown to effectively form ionic bonds to hydroxyapatite [10]. Higher and more stable $\mu$ TBS with reduced nanoleakage at the interfaces were demonstrated after six months of water storage [52]. A recent in vitro-study on SBU also supported the concept that a stable chemical bonding by 10-MDP to calcium (10-MDP-Ca nano-layering) is advantageous for the durability of the adhesive-dentin bond [53]. SBU in contrast to OFL seems to be more predestinated to form a stable cumulative chemical plus micromechanical bond to sclerotic dentin. The lower median increase of adhesive defects to the dentin also suggests that the cumulative chemical and micromechanical bond is more stable over time compared to the pure mechanical bond with OFL. This may explain the higher distribution of values for adhesive defects in the OFL group, which could be interpreted as a sign of higher technical sensitivity of the etch-andrinse adhesive. 
Basically, it is known, that additional $\mathrm{H}_{3} \mathrm{PO}_{4}$-gel conditioning on the prepared dentin before application of a SEA reduces the bond strength when compared to the SE approach [4]. One might speculate that overetching in SEE conditioning could negatively impact the bonding performance of universal adhesives, which in principle represent further developments of the SEAs. At first glance, the opposite results were observed in this study. Starting from 6 months, adhesive defects increased at sclerotic dentin/cement in group SBU-SE compared to SBUSEE. A possible explanation could be that in self-etch application, less micromechanical bonding was achieved compared to in the SEE group, where unintentional acid conditioning of the dentin has resulted in a cumulation of chemical and micromechanical bonding. Therefore, it could be assumed that phosphoric acid etching of dentin might be advantageous in NCCLs if universal adhesives are used [19].

The clinical benefit of selective enamel etching before application of a SE adhesive system has been widely described. Therefore, the SBUSEE mode was chosen as a modification of the self-etch approach since it represents the clinically more relevant application compared to the SBU-ER mode for a further developed self-etch adhesive. While the clinical retention is not significantly affected by this, an additional enamel etching [1] might improve marginal adaptation and minimize marginal staining of cervical composite restorations [3,5]. Both could also be confirmed in the present results clinically as well as by OCT with significant reduced adhesive defects after enamel etching, already visible after restoration placement. Before the application of the mild $\mathrm{SBU}(\mathrm{pH}=2.7)$, selective enamel etching is an advisable strategy to improve the bond strength to enamel [11,42,54]. In addition, a fourarm study has already been initiated which, due to the difficulty of finding volunteers with 4 equivalent lesions, has a reduced number of subjects per group $(\mathrm{n}=22)$. In this study, Scotchbond Universal was additionally used in etch-and-rinse mode and the 6-month results are currently available. [19].

Another possibility to optimize the conditioning could be to prolong the application time of universal adhesives if used in SE mode. Regarding enamel, a prolonged use up to $40 \mathrm{~s}$ was advised to reduce the marginal deterioration [55], which could be a viable alternative to increase the etching pattern, and resin-enamel bond strength and to improve the marginal adaptation. Whether this approach also has a positive effect on dentin adhesion in NCCLs remains currently unclear.

The use of OCT in this clinical trial has made it possible to longitudinally visualize early signs of adhesive failure at the entire interface between tooth and restoration. Significant group differences detected with OCT, which are not verifiable in the clinic, show that the tomographic evaluation of composite restorations is more sensitive and more valid than the clinical evaluation. Although restorations statistically showed more interfacial adhesive defects prior to its loss, it is not possible to predict the loss for a single restoration. However, interfacial defects could be an important predictor of the clinical success of a restoration system. This was already supposed after six months of observation [19] and could be confirmed in this study. The application of OCT could thus enable shorter clinical trials and/or lower patient numbers in the future [19].Further statements are to be expected after the planned total observation time of this investigation after 36 months.

\section{Conclusions}

- After 12 months in vivo, clinical evaluation and OCT imaging revealed higher interfacial integrity for Scotchbond Universal in selfetch and selective-enamel-etch mode compared to the etch-andrinse gold standard.

- Selective enamel etching is recommended prior to application of Scotchbond Universal to enhance the clinical performance.

- The OCT parameter interfacial adhesive defect seems to be a valuable predictor for evaluation of adhesive restoration systems.

\section{Author's contributions}

R. Haak contributed to conception, design, data analysis and interpretation, wrote and revised the manuscript. M. Hähnel contributed to data acquisition, analysis and interpretation, wrote the manuscript. M. Häfer and H. Schneider contributed to conception, design, data acquisition, analysis and interpretation, wrote the manuscript. K.-J. Park critically revised the manuscript. D. Ziebolz contributed to design and critically revised the manuscript. M. Rosolowski supported statistical analysis. All authors gave final approval of the work.

\section{Funding}

The study was financially supported by $3 \mathrm{M}$ Deutschland $\mathrm{GmbH}$ and funding for the OCT equipment was provided by the European Fund for Regional Development (EFRE-Grant 100175024).

The authors declare the following financial interests/personal relationships which may be considered as potential competing interests:

\section{Declaration of Competing Interest}

The authors do not have any financial interest in the companies whose materials are included in this article and certify that all financial and material support for this research and work are acknowledged in the manuscript. $3 \mathrm{M}$ Deutschland $\mathrm{GmbH}$ was consulted in defining the aim of the study but had no role in design and conduct of the study as well as in analysis and interpretation of the data.

\section{Acknowledgments}

The authors would like to thank Patrick Schmidt and Claudia Rüger for their support in the data acquisition process as well as Tobias Meissner and Conny Köhler for professional technical assistance.

\section{References}

[1] M. Peumans, J. de Munck, A. Mine, B. van Meerbeek, Clinical effectiveness of contemporary adhesives for the restoration of non-carious cervical lesions. A systematic review, Dent. Mater. 30 (10) (2014) 1089-1103, https://doi.org/10.1016/ j.dental.2014.07.007.

[2] B. van Meerbeek, K. Yoshihara, Y. Yoshida, A. Mine, J. de Munck, K.L. van Landuyt, State of the art of self-etch adhesives, Dent. Mater. 27 (1) (2011) 17-28, https://doi. org/10.1016/j.dental.2010.10.023.

[3] M. Schroeder, I.C. Correa, J. Bauer, A.D. Loguercio, A. Reis, Influence of adhesive strategy on clinical parameters in cervical restorations: a systematic review and meta-analysis, J. Dent. 62 (7) (2017) 36-53, https://doi.org/10.1016/j.jdent.2017. 05.006

[4] R. Frankenberger, U. Lohbauer, M.J. Roggendorf, M. Naumann, M. Taschner, Selective enamel etching reconsidered: better than etch-and-rinse and self-etch? J. Adhes. Dent. 10 (5) (2008) 339-344.

[5] A. Szesz, S. Parreiras, A. Reis, A. Loguercio, Selective enamel etching in cervical lesions for self-etch adhesives: a systematic review and meta-analysis, J. Dent. 53 (10) (2016) 1-11, https://doi.org/10.1016/j.jdent.2016.05.009.

[6] M. Peumans, J. de Munck, K.L. van Landuyt, A. Poitevin, P. Lambrechts, B. van Meerbeek, Eight-year clinical evaluation of a 2-step self-etch adhesive with and without selective enamel etching, Dent. Mater. 26 (12) (2010) 1176-1184, https:// doi.org/10.1016/j.dental.2010.08.

[7] W. Qin, L. Lei, Q.-T. Huang, L. Wang, Z.-M. Lin, Clinical effectiveness of self-etching adhesives with or without selective enamel etching in noncarious cervical lesions: a systematic review, J. Dent. Sci. 9 (4) (2014) 303-312, https://doi.org/10.1016/j. jds.2014.03.002

[8] F. Tian, L. Zhou, Z. Zhang, L. Niu, L. Zhang, C. Chen, J. Zhou, H. Yang, X. Wang, B. Fu, C. Huang, D.H. Pashley, F.R. Tay, Paucity of nanolayering in resin-dentin interfaces of MDP-based adhesives, J. Dent. Res. 95 (4) (2016) 380-387, https:// doi.org/10.1177/0022034515623741.

[9] K. Yoshihara, S. Hayakawa, N. Nagaoka, T. Okihara, Y. Yoshida, B. van Meerbeek, Etching efficacy of self-etching functional monomers, J. Dent. Res. 97 (9) (2018) 1010-1016, https://doi.org/10.1177/0022034518763606.

[10] K. Yoshihara, Y. Yoshida, N. Nagaoka, D. Fukegawa, S. Hayakawa, A. Mine, M. Nakamura, S. Minagi, A. Osaka, K. Suzuki, B. van Meerbeek, Nano-controlled molecular interaction at adhesive interfaces for hard tissue reconstruction, Acta Biomater. 6 (9) (2010) 3573-3582, https://doi.org/10.1016/j.actbio.2010.03.024.

[11] J. Perdigão, A.D. Loguercio, Universal or multi-mode adhesives: why and how? J. Adhes. Dent. 16 (2) (2014) 193-194, https://doi.org/10.3290/j.jad.a31871.

[12] A. Wagner, M. Wendler, A. Petschelt, R. Belli, U. Lohbauer, Bonding performance of 
universal adhesives in different etching modes, J. Dent. 42 (7) (2014) 800-807, https://doi.org/10.1016/j.jdent.2014.04.012.

[13] C. Chen, L.-N. Niu, H. Xie, Z.-Y. Zhang, L.-Q. Zhou, K. Jiao, J.-H. Chen, D.H. Pashley, F.R. Tay, Bonding of universal adhesives to dentine - Old wine in new bottles? J. Dent. 43 (5) (2015) 525-536, https://doi.org/10.1016/j.jdent.2015.03. 004 .

[14] M.A. Muñoz, I. Luque, V. Hass, A. Reis, A.D. Loguercio, N.H.C. Bombarda, Immediate bonding properties of universal adhesives to dentine, J. Dent. 41 (5) (2013) 404-411, https://doi.org/10.1016/j.jdent.2013.03.001.

[15] T. Suzuki, T. Takamizawa, W.W. Barkmeier, A. Tsujimoto, H. Endo, R.L. Erickson, M.A. Latta, M. Miyazaki, Influence of etching mode on enamel bond durability of universal adhesive systems, Oper. Dent. 41 (5) (2016) 520-530, https://doi.org/10. 2341/15-347-L.

[16] A.C. Diniz, M.C. Bandeca, L.M. Pinheiro, L.J. Dos Santosh Almeida Jr, C.R. Torres, A.H. Borges, S.C. Pinto, M.R. Tonetto, R.R. De Jesus Tavarez, L.M. Firoozmand, Influence of different etching modes on bond strength to enamel using universal adhesive systems, J. Contemp. Dent. Pract. 17 (10) (2016) 820-825.

[17] S.D. Heintze, Systematic reviews: I. The correlation between laboratory tests on marginal quality and bond strength. II. The correlation between marginal quality and clinical outcome, J. Adhes. Dent. 9 (6) (2007) 77-106.

[18] M. Häfer, H. Jentsch, R. Haak, H. Schneider, A three-year clinical evaluation of a one-step self-etch and a two-step etch-and-rinse adhesive in non-carious cervical lesions, J. Dent. 43 (3) (2015) 350-361, https://doi.org/10.1016/j.jdent.2014.12 009.

[19] R. Haak, P. Schmidt, K.-J. Park, M. Häfer, F. Krause, D. Ziebolz, H. Schneider, OCT for early quality evaluation of tooth-composite bond in clinical trials, J. Dent. 76 (9) (2018) 46-51, https://doi.org/10.1016/j.jdent.2018.06.007.

[20] H. Schneider, A.S. Steigerwald-Otremba, M. Häfer, F. Krause, M. Scholz, R. Haak, Is optical coherence tomography a potential tool to evaluate marginal adaptation of class III/IV composite restorations in vivo? Oper. Dent. 44 (3) (2018) 242-253, https://doi.org/10.2341/17-192-C.

[21] B. van Meerbeek, M. Peumans, A. Poitevin, A. Mine, A. van Ende, A. Neves, J. de Munck, Relationship between bond-strength tests and clinical outcomes, Dent Mater. 26 (2) (2010) 100-121, https://doi.org/10.1016/j.dental.2009.11.148.

[22] S.D. Heintze, C. Thunpithayakul, S.R. Armstrong, V. Rousson, Correlation between microtensile bond strength data and clinical outcome of Class V restorations, Dent Mater. 27 (2) (2011) 114-125, https://doi.org/10.1016/j.dental.2010.09.005.

[23] H.M.C. Rêgo, T.S. Alves, E. Bresciani, L.-N. Niu, F.R. Tay, C.R. Pucci, Can long-term dentine bonding created in real life be forecasted by parameters established in the laboratory? Sci. Rep. 6 (11) (2016) 37799, https://doi.org/10.1038/srep37799.

[24] M. Häfer, H. Schneider, S. Rupf, I. Busch, A. Fuchß, I. Merte, H. Jentsch, R. Haak, $\mathrm{K}$. Merte, Experimental and clinical evaluation of a self-etching and an etch-andrinse adhesive system, J. Adhes. Dent. 15 (3) (2013) 275-286, https://doi.org/10. 3290/j.jad.a29633.

[25] S.D. Heintze, V. Rousson, E. Mahn, Bond strength tests of dental adhesive systems and their correlation with clinical results - a meta-analysis, Dent. Mater. 31 (4) (2015) 423-434, https://doi.org/10.1016/j.dental.2015.01.011.

[26] R. Pecie, I. Krejci, F. García-Godoy, T. Bortolotto, Noncarious cervical lesions (NCCL) - a clinical concept based on the literature review. Part 2: restoration, Am. Dent. J. 24 (3) (2011) 183-192.

[27] T.A. Bakhsh, A. Sadr, Y. Shimada, J. Tagami, Y. Sumi, Non-invasive quantification of resin-dentin interfacial gaps using optical coherence tomography: validation against confocal microscopy, Dent. Mater. 27 (9) (2011) 915-925, https://doi.org/ 10.1016/j.dental.2011.05.003.

[28] S.-H. Han, A. Sadr, J. Tagami, S.-H. Park, Non-destructive evaluation of an internal adaptation of resin composite restoration with swept-source optical coherence tomography and micro-CT, Dent. Mater. 32 (1) (2016) 1-7, https://doi.org/10.1016/ j.dental.2015.

[29] H. Schneider, K.-J. Park, C. Rueger, D. Ziebolz, F. Krause, R. Haak, Imaging resin infiltration into non-cavitated carious lesions by optical coherence tomography, J. Dent. 60 (5) (2017) 94-98, https://doi.org/10.1016/j.jdent.2017.03.004.

[30] ADA Council on Scientific Affairs., ADA Council on Scientific Affairs. American Dental Association Acceptance Program Guidelines - Dentin and Enamel Adhesive Materials, (2001), pp. 1-9.

[31] B.G. Smith, J.K. Knight, An index for measuring the wear of teeth, Br. Dent. J. 156 (12) (1984) 435-438, https://doi.org/10.1038/sj.bdj.4805394.

[32] R. Hickel, J.-F. Roulet, S. Bayne, S.D. Heintze, I.A. Mjor, M. Peters, V. Rousson, R. Randall, G. Schmalz, M. Tyas, G. Vanherle, Recommendations for conducting controlled clinical studies of dental restorative materials. Science Committee Project 2/98-FDI World Dental Federation study design (Part I) and criteria for evaluation (Part II) of direct and indirect restorations including onlays and partial crowns, J. Adhes. Dent. 9 (Suppl 1) (2007) 121-147.

[33] A. Mena-Serrano, C. Kose, E.A. de Paula, L.Y. Tay, A. Reis, A.D. Loguercio, J. Perdigão, A new universal simplified adhesive: 6-month clinical evaluation, J. Esthet. Restor. Dent. 25 (1) (2013) 55-69, https://doi.org/10.1111/jerd.12005.

[34] J. Perdigão, C. Kose, A.P. Mena-Serrano, E.A. de Paula, L.Y. Tay, A. Reis,
A.D. Loguercio, A new universal simplified adhesive: 18-month clinical evaluation, Oper. Dent. 39 (2) (2014) 113-127, https://doi.org/10.2341/13-045-C.

[35] A.D. Loguercio, E.A. de Paula, V. Hass, I. Luque-Martinez, A. Reis, J. Perdigão, A new universal simplified adhesive: 36 -Month randomized double-blind clinical trial, J. Dent. 43 (9) (2015) 1083-1092, https://doi.org/10.1016/j.jdent.2015.07. 005 .

[36] N.C. Lawson, A. Robles, C.C. Fu, C.P. Lin, K. Sawlani, J.O. Burgess, Two-year clinical trial of a universal adhesive in total-etch and self-etch mode in non-carious cervical lesions, J. Dent. 43 (10) (2015) 1229-1234, https://doi.org/10.1016/j. jdent.2015.07.009.

[37] M. Peumans, L. Wouters, J. de Munck, B. van Meerbeek, K. van Landuyt, Nine-year clinical performance of a HEMA-free one-step self-etch adhesive in noncarious cervical lesions, J. Adhes. Dent. 20 (3) (2018) 195-203, https://doi.org/10.3290/j jad.a40630.

[38] M. Peumans, J. de Munck, K.L. van Landuyt, A. Poitevin, P. Lambrechts, B. van Meerbeek, A 13-year clinical evaluation of two three-step etch-and-rinse adhesives in non-carious class-V lesions, Clin. Oral Invest. 16 (1) (2012) 129-137, https://doi. org/10.1007/s00784-010-0481-z.

[39] E.U. Celik, B. Aka, F. Yilmaz, Six-month clinical evaluation of a self-adhesive flowable composite in noncarious cervical lesions, J. Adhes. Dent. 17 (4) (2015) 361-368, https://doi.org/10.3290/j.jad.a34556.

[40] E.A. de Paula, L.Y. Tay, C. Kose, A. Mena-Serrano, A. Reis, J. Perdigão, A.D. Loguercio, Randomized clinical trial of four adhesion strategies in cervical lesions: 12-month results, Int. J. Esthet. Dent. 10 (1) (2015) 122-145.

[41] K.L. van Landuyt, J. de Munck, R.B. Ermis, M. Peumans, B. van Meerbeek, Five-year clinical performance of a HEMA-free one-step self-etch adhesive in noncarious cervical lesions, Clin. Oral Investig. 18 (4) (2014) 1045-1052, https://doi.org/10 1007/s00784-013-1061-9.

[42] P.M. Vermelho, A.F. Reis, G.M.B. Ambrosano, M. Giannini, Adhesion of multimode adhesives to enamel and dentin after one year of water storage, Clin. Oral Investig. 21 (5) (2017) 1707-1715, https://doi.org/10.1007/s00784-016-1966-1.

[43] J. de Munck, A. Poitevin, A.K. Lührs, P. Pongprueksa, A. van Ende, K.L. van Landuyt, B. van Meerbeek, Interfacial fracture toughness of aged adhesive-dentin interfaces, Dent. Mater. 31 (4) (2015) 462-472, https://doi.org/10.1016/j.dental. 2015.01.017.

[44] R.F. Zanatta, M. Lungova, A.B. Borges, C. Torres, H.G. Sydow, A. Wiegand, Microleakage and shear bond strength of composite restorations under cycling conditions, Oper. Dent. 42 (2) (2017) E71-E80, https://doi.org/10.2341/16-132-L.

[45] R.M. Carvalho, A.P. Manso, S. Geraldeli, F.R. Tay, D.H. Pashley, Durability of bonds and clinical success of adhesive restorations, Dent. Mater. 28 (1) (2012) 72-86, https://doi.org/10.1016/j.dental.2011.09.011.

[46] J. Perdigão, Dentin bonding-variables related to the clinical situation and the substrate treatment, Dent. Mater. 26 (2) (2010) 24-37, https://doi.org/10.1016/j dental.2009.11.149.

[47] K. Karan, X. Yao, C. Xu, Y. Wang, Chemical profile of the dentin substrate in noncarious cervical lesions, Dent. Mater. 25 (10) (2009) 1205-1212, https://doi.org/ 10.1016/j.dental.2009.04.006.

[48] C. Xie, Y. Han, X.-Y. Zhao, Z.-Y. Wang, H.-M. He, Microtensile bond strength of oneand two-step self-etching adhesives on sclerotic dentin: the effects of thermocycling, Oper. Dent. 35 (5) (2010) 547-555, https://doi.org/10.2341/10-025-L.

[49] S. Kwong, Micro-tensile bond strengths to sclerotic dentin using a self-etching and a total-etching technique, Dent. Mater. 18 (5) (2002) 359-369, https://doi.org/10. 1016/S0109-5641(01)00051-3.

[50] E. Mahn, V. Rousson, S. Heintze, Meta-analysis of the influence of bonding parameters on the clinical outcome of tooth-colored cervical restorations, J. Adhes. Dent. 17 (5) (2015) 391-403, https://doi.org/10.3290/j.jad.a35008.

[51] A.D. Loguercio, I.V. Luque-Martinez, S. Fuentes, A. Reis, M.A. Muñoz, Effect of dentin roughness on the adhesive performance in non-carious cervical lesions: a double-blind randomized clinical trial, J. Dent. 69 (2) (2018) 60-69, https://doi org/10.1016/j.jdent.2017.09.011.

[52] M.A. Muñoz, I. Luque-Martinez, P. Malaquias, V. Hass, A. Reis, N.H. Campanha, A.D. Loguercio, In vitro longevity of bonding properties of universal adhesives to dentin, Oper. Dent. 40 (3) (2015) 282-292, https://doi.org/10.2341/14-055-L.

[53] R. Wang, Y. Shi, T. Li, Y. Pan, Y. Cui, W. Xia, Adhesive interfacial characteristics and the related bonding performance of four self-etching adhesives with different functional monomers applied to dentin, J. Dent. 62 (5) (2017) 72-80, https://doi. org/10.1016/j.jdent.2017.05.010.

[54] T. Sato, T. Takagaki, N. Matsui, H. Hamba, A. Sadr, T. Nikaido, J. Tagami, Morphological evaluation of the adhesive/enamel interfaces of two-step selfetching adhesives and multimode one-bottle self-etching adhesives, J. Adhes. Dent. 18 (3) (2016) 223-229, https://doi.org/10.3290/j.jad.a36135.

[55] A.M. Cardenas, F. Siqueira, J. Rocha, A.L. Szesz, M. Anwar, F. El-Askary, A. Reis, A. Loguercio, Influence of conditioning time of universal adhesives on adhesive properties and enamel-etching pattern, Oper. Dent. 41 (5) (2016) 481-490, https:// doi.org/10.2341/15-213-L. 


\section{Zusammenfassung}

Dissertation zur Erlangung des akademischen Grades Dr. med. dent.

Titel:

Clinical and OCT outcomes of a universal adhesive in a randomized clinical trial after 12 months

eingereicht von: Marcus Hähnel

angefertigt an: $\quad$ Universitätsklinikum Leipzig AÖR

Poliklinik für Zahnerhaltung und Parodontologie

betreut von: $\quad$ Univ.-Prof. Dr. med. dent. Rainer Haak, MME

Dr. rer. nat. Hartmut Schneider

eingereicht im: $\quad$ Februar 2020

In der vorliegenden prospektiven klinischen Studie wurden Kompositrestaurationen nichtkariöser Zahnhalsdefekte, die mit einem Universaladhäsiv in zwei Applikationsmodi gelegt wurden, klinisch und mithilfe der optischen Kohärenztomografie (OCT) beurteilt. Als Kontrollgruppe diente ein Etch-and-rinse-Referenzadhäsiv.

Hierzu wurden 55 Patienten mit jeweils drei nichtkariösen Zahnhalsdefekten in der Frontzahn/Prämolaren-Region mit dem Komposit Filtek Supremeтм XTE versorgt. Als Adhäsive dienten in den Testgruppen das Universaladhäsiv Scotchbond Universalтм (SBU) und als Kontrolle das etablierte Etch-and-rinse-Adhäsiv OptibondTM FL (OFL). Das Universaladhäsiv wurde in den Konditionierungsmodi self-etch (SE) und selective-enamel- 
etch (SEE) angewendet. Die Bewertung der Restaurationen erfolgte mit OCT direkt nach Füllungslegung (to) sowie klinisch und mit OCT nach 14 Tagen ( $\mathrm{t}_{1}$, baseline), sechs und 12 Monaten. Die klinische Beurteilung erfolgte nach den FDI-Kriterien (Hickel 2007) [45]. Zur Bewertung des Verbundversagens wurde an einer äquidistanten Auswahl von 25 der ca. 300 OCT-B-Scans pro Füllung die mittlere Länge für adhäsiven Defekt (\%) separat für die Schmelz- und Dentin/Zement-Komposit-Interface ermittelt. Die Gruppenvergleiche erfolgten mit dem Friedman-/Wilcoxon- (OCT) und McNemar-Test (Klinik).

\section{Klinische Untersuchung}

Nach 12 Monaten konnten 154 von 165 Restaurationen klinisch bewertet und tomografisch abgebildet werden.

Alle Füllungsverluste, die sich aus einem teilweisen oder vollständigen Retentionsverlust ergaben, traten in der Referenzgruppe OFL auf. Nach sechs Monaten waren das neun und nach 12 Monaten weitere zwei Verluste, was in der Gruppe OFL zu einer kumulativen Fehlerrate von 20,0 \% führte. Die Kaplan-Meier-Kurven unterscheiden sich nach sechs und 12 Monaten zwischen jeder der beiden SBU-Gruppen und der Gruppe OFL signifikant. Im Studienverlauf wurden in keiner der SBU-Gruppen Restaurationsverluste beobachtet und alle Versorgungen wurden bzgl. der klinischen Parameter als akzeptabel bewertet (Score 1 oder 2).

Das Kriterium Randverfärbung wurde in Gruppe OFL gegenüber Gruppe SBU-SEE signifikant häufiger mit Score 2 bewertet, nicht jedoch gegenüber Gruppe SBU-SE. Ein signifikanter Unterschied zeichnete sich auch im Gruppenvergleich SBU-SE vs. SBU-SEE $(23,6 \%$ vs. $1,8 \%)$ ab. Für den Parameter marginale Adaptation ergaben sich signifikante Gruppenunterschiede lediglich im Vergleich SBU-SE > SBU-SEE.

Mit Ausnahme der Gruppe SBU-SEE beim Kriterium Randverfärbung, konnte für alle Gruppen eine signifikante Verschiebung von Score $1 \mathrm{zu}$ Score 2 nach 12 Monaten bei Randverfärbung und marginale Adaptation beobachtet werden. 


\section{OCT - Zahn-Komposit-Verbundversagen}

Die Quantifizierung der interfazialen adhäsiven Defekte erfolgte direkt nach Füllungslegung (initial) und nach sechs und 12 Monaten getrennt für die Schmelz- und Dentin/ZementKomposit-Interface. Die Gruppenunterschiede wurden zu jedem Zeitpunkt zwischen den Gruppen und über die Periode von initial bis 12 Monate für jede Gruppe statistisch bewertet. In allen Gruppen erschienen zu jedem Zeitpunkt interfaziale adhäsive Defekte an der Schmelz- und Dentin/Zement-Komposit-Interface. Mit einem Längenanteil von 85,2\% dominierte die Dentin/Zement-Komposit-Interface gegenüber der Schmelzinterface.

\section{Schmelz-Komposit-Interface}

In der Gruppe SBU-SE zeigten sich zu jedem Zeitpunkt signifikant mehr adhäsive Defekte als in den anderen Gruppen. In der Gruppe OFL zeigten sich nach sechs Monaten signifikant und nach 12 Monaten tendenziell mehr Defekte als mit SBU im Modus SEE. Bis 12 Monate nahmen die interfazialen Spalten in allen Gruppen im Vergleich zum Ausgangswert signifikant zu. Die Streuung der Werte war in der Gruppe SBU-SE am höchsten. Die initial darstellbaren Gruppenunterschiede waren zu den nachfolgenden Untersuchungszeitpunkten reproduzierbar.

\section{Dentin/Zement-Komposit-Interface}

In der Referenzgruppe OFL wurden zu allen Zeitpunkten signifikant mehr Defekte als in den Gruppen SBU-SE und SBU-SEE festgestellt. Ab sechs Monaten wurden in der Gruppe SBU-SEE signifikant weniger adhäsive Defekte im Vergleich zur SBU-SE Gruppe beobachtet. Für die Periode sechs bis 12 Monate ergab sich für alle Gruppen ein signifikanter Zuwachs der interfazialen Spaltformation. Die Gruppen SBU-SE und OFL zeigten nach 12 Monaten signifikant mehr adhäsive Defekte als initial. Die größte Streuung der Werte ergab sich sowohl nach sechs als auch nach 12 Monaten in der Gruppe OFL. Die Gruppenunterschiede zu den jeweiligen Untersuchungszeitpunkten waren über den gesamten Zeitraum reproduzierbar. 
Die Ergebnisse der tomografischen Untersuchung lassen sich wie folgt zusammenfassen: Mit SBU wurden im Modus SEE unabhängig vom Zahnsubstrat nach 12 Monaten signifikant weniger interfaziale adhäsive Defekte detektiert als im Modus SBU-SE. Mit OFL ergaben sich an der Dentin/Zement-Komposit-Interface generell signifikant mehr adhäsive Defekte als mit SBU in beiden Modi und ab sechs Monaten am Schmelz mehr als in der Gruppe SBUSEE. In der gesamten Periode nahmen in jeder Gruppe die interfazialen Spalten zu. Die über die Zeit darstellbaren signifikanten Gruppenunterschiede waren weitestgehend reproduzierbar.

Des Weiteren streuten die Werte am Schmelz für die Gruppe SBU-SEE und an der Dentin/Zement-Komposit-Interface mit SBU in beiden Modi am geringsten, was auf eine geringere Techniksensitivität bei der Anwendung des Universaladhäsivs hinweist.

\section{Klinik \& OCT}

Das bereits nach Füllungslegung in der Kontrollgruppe OFL signifikant erhöhte Verbundversagen an der Dentin/Zement-Komposit-Interface korrespondiert mit dem signifikant häufigeren Auftreten von Füllungsverlusten nach sechs Monaten. Dieser Zusammenhang wurde nach 12 Monaten bestätigt. Bei den verloren gegangenen Restaurationen waren vor dem Verlust um 25 \% - 39 \% erhöhte interfaziale Spaltformationen an der Dentin/Zement-Komposit-Interface zu verzeichnen.

Die Gruppenunterschiede in den klinischen Parametern Randverfärbung und marginale Adaptation spiegelten sich ebenfalls in den Gruppenunterschieden zu adhäsivem Defekt sechs bis 12 Monate früher wieder.

Mit dem Universaladhäsiv Scotchbond Universal wurde nach 12 Monaten in vivo ein höherwertiger Zahn-Komposit-Verbund erzielt. Auch war an NCCLs die Streuung der Messwerte für interfazialen Spalt am Dentin im Vergleich zum Kontrollsystem OFL vermindert, wobei gezeigt werden konnte, dass selektive Schmelzätzung gegenüber dem Self-etch-Modus den Schmelz-Komposit-Verbund steigert. Eine häufig unvermeidbare 
Dentinkonditionierung mit Phosphorsäure wirkt sich bei NCCLs nicht negativ auf den adhäsiven Verbund aus.

Durch Anwendung der OCT war es möglich, in vivo an Klasse-V-Restaurationen den adhäsiven Verbund zwischen Zahn und Komposit entlang der gesamten Interface zwischen Zahnhartsubstanzen und Restaurationen abzubilden. Über den gesamten Untersuchungszeitraum konnten dieselben Interfaces visualisiert und quantitativ bewertet werden (Monitoring), so dass es möglich war, Gruppenunterschiede mit einer hohen statistischen Power darzustellen (s. p-Werte).

Mit diesem sensitiven Verfahren konnten so signifikante Gruppenunterschiede im Vergleich zur klinischen Bewertung sechs bis 12 Monate im Vorlauf dargestellt werden. Obwohl sich Retentionsverluste statistisch durch ausgedehntere interfaziale Spaltformationen ankündigen und vor Verlust ausgedehntere adhäsive Defekte nachweisbar sind, kann das Verlustereignis für die einzelne Füllung aber nicht vorhergesagt werden. Die Ergebnisse der Studie lassen jedoch den Schluss zu, dass interfaziale Defekte einen entscheidenden Faktor für „klinischen Erfolg" von Restaurationen darstellen und daher neben anderen Parametern eine hohe prädiktive Wertigkeit besitzen. Einem auf optischer Kohärenztomografie basierenden Monitoring des Zahn-Komposit-Verbundes bzw. -Verbundversagens ist daher eine besondere Bedeutung zuzuschreiben. Dies könnte dazu beitragen, klinische Studien zu verkürzen und ggf. auch kleinere Patientenzahlen zu ermöglichen. 


\section{Literaturverzeichnis}

1. Buonocore MG. A Simple Method of Increasing the Adhesion of Acrylic Filling Materials to Enamel Surfaces. J Dent Res. Dezember 1955;34(6):849-53.

2. De Munck J, Van Landuyt K, Peumans M, Poitevin A, Lambrechts P, Braem M, u. a. A critical review of the durability of adhesion to tooth tissue: methods and results. J Dent Res. Februar 2005;84(2):118-32.

3. Van Meerbeek B, Peumans M, Poitevin A, Mine A, Van Ende A, Neves A, u. a. Relationship between bond-strength tests and clinical outcomes. Dent Mater. Februar 2010;26(2):e100-21.

4. Peumans M, De Munck J, Mine A, Van Meerbeek B. Clinical effectiveness of contemporary adhesives for the restoration of non-carious cervical lesions. A systematic review. Dent Mater. Oktober 2014;30(10):1089-103.

5. Qin W, Lei L, Huan QT, Wang L. Clinical effectiveness of self-etching adhesives with or without selective enameletching in noncarious cervical lesions: A systematic review: J Dent Sci. 2014;9(303-312).

6. Taschner M, Nato F, Mazzoni A, Frankenberger R, Falconi M, Petschelt A, u. a. Influence of preliminary etching on the stability of bonds created by one-step self-etch bonding systems. Eur J Oral Sci. Juni 2012;120(3):239-48.

7. Van Landuyt KL, Kanumilli P, De Munck J, Peumans M, Lambrechts P, Van Meerbeek B. Bond strength of a mild self-etch adhesive with and without prior acid-etching. J Dent. Januar 2006;34(1):77-85.

8. Tay FR, Pashley DH, Yoshiyama M. Two modes of nanoleakage expression in singlestep adhesives. J Dent Res. Juli 2002;81(7):472-6.

9. Dörfer CE, Staehle HJ, Wurst MW, Duschner H, Pioch T. The nanoleakage phenomenon: influence of different dentin bonding agents, thermocycling and etching time. Eur J Oral Sci. August 2000;108(4):346-51.

10. Van Meerbeek B, Yoshihara K, Yoshida Y, Mine A, J. DM, K.L. VL. State of the art of self-etch adhesives. Dent Mater. Januar 2011;27(1):17-28.

11. Van Meerbeek B, De Munck J, Yoshida Y, Inoue S, Vargas M, Vijay P, u. a. Buonocore memorial lecture. Adhesion to enamel and dentin: current status and future challenges. Oper Dent. Juni 2003;28(3):215-35.

12. Mena-Serrano A, Kose C, De Paula EA, Tay LY, Reis A, Loguercio AD, Perdigão J. A new universal simplified adhesive: 6-month clinical evaluation. J Esthet Restor Dent. 2013;25(1):55-69.

13. Marchesi G, Frassetto A, Mazzoni A, Apolonio F, Diolosà M, Cadenaro M, Di Lenarda R, Pashley DH, Tay F, Breschi L. Adhesive performance of a multi-mode adhesive system: 1-year in vitro study. J Dent. 2014;42(5):603-612.

14. Chen C, Niu L-N, Xie H, Zhang Z-Y, Zhou L-Q, Jiao K, u. a. Bonding of universal adhesives to dentine - Old wine in new bottles? J Dent. Mai 2015;43(5):525-36.

15. Tian F, Zhou L, Zhang Z, Niu L, Zhang L, Chen C, u. a. Paucity of nanolayering in resindentin interfaces of MDP-based adhesives. J Dent Res. 2016;95(4):380-387. 
16. Yoshihara K, Yoshida Y, Nagaoka N, Fukegawa D, Hayakawa S, Mine A, u. a. Nanocontrolled molecular interaction at adhesive interfaces for hard tissue reconstruction. Acta Biomater. September 2010;6(9):3573-82.

17. Haak R, Schmidt P, Park K-J, Häfer M, Krause F, Ziebolz D, u. a. OCT for early quality evaluation of tooth-composite bond in clinical trials. J Dent. 2018;76:46-51.

18. Wagner A, Wendler M, Petschelt A, Belli R, Lohbauer U. Bonding performance of universal adhesives in different etching modes. J Dent. Juli 2014;42(7):800-7.

19. Munoz et al. In vitro longevity of bonding properties of universal adhesives to dentin. Oper Dent 2015.

20. Roulet JF. Marginal integrity: clinical significance. J Dent. 1994;22 Suppl 1:S9-12.

21. Carvalho RM, Manso AP, Geraldeli S, Tay FR, Pashley DH. Durability of bonds and clinical success of adhesive restorations. Dent Mater Off Publ Acad Dent Mater. Januar 2012;28(1):72-86.

22. Heintze SD. Clinical relevance of tests on bond strength, microleakage and marginal adaptation. Dent Mater. Januar 2013;29(1):59-84.

23. Coutinho E, Cardoso MV, Fernandes CP, Neves AA, Gouvea CVD, Van Landuyt KL, u. a. Nanoleakage Distribution at Adhesive-Dentin Interfaces in 3D. J Dent Res. August 2011;90(8):1019-25.

24. Wendt SL, Mclnnes PM, Dickinson GL. The effect of thermocycling in microleakage analysis. Dent Mater Off Publ Acad Dent Mater. Mai 1992;8(3):181-4.

25. Heintze SD, Zimmerli B. Relevance of in vitro tests of adhesive and composite dental materials, a review in 3 parts. Part 1: Approval requirements and standardized testing of composite materials according to ISO specifications. Schweiz Monatsschrift Zahnmed Rev Mens Suisse Odonto-Stomatol Riv Mens Svizzera Odontol E Stomatol. 2011;121(9):804-16.

26. Hasegawa $\mathrm{T}$, Retief $\mathrm{DH}$. Quantitative microleakage of some dentinal bonding restorative systems. Dent Mater Off Publ Acad Dent Mater. März 1993;9(2):114-7.

27. Mandras RS, Retief DH, Russell CM. Quantitative microleakage of six dentin bonding systems. Am J Dent. Juni 1993;6(3):119-22.

28. Ernst C, Galler P, Willershausen B, Haller B. Marginal integrity of class $V$ restorations: SEM versus dye penetration. Dent Mater. März 2008;24(3):319-27.

29. Schneider H, Steigerwald-Otremba AS, Häfer M, Krause F, Scholz M, Haak R. Is Optical Coherence Tomography a Potential Tool to Evaluate Marginal Adaptation of Class III/IV Composite Restorations In Vivo? Oper Dent. Juni 2019;44(3):242-53.

30. Haak R, Wicht MJ, Hellmich M, Noack MJ. Detection of marginal defects of composite restorations with conventional and digital radiographs. Eur J Oral Sci. August 2002;110(4):282-6.

31. Häfer M, Jentsch $H$, Haak R, Schneider H. A three-year clinical evaluation of a one-step self-etch and a two-step etch-and-rinse adhesive in non-carious cervical lesions. J Dent. März 2015;43(3):350-61. 
32. Monteiro GQM, Montes MAJR, Gomes ASL, Mota CCBO, Campello SL, Freitas AZ. Marginal analysis of resin composite restorative systems using optical coherence tomography. Dent Mater. Dezember 2011;27(12):e213-23.

33. Park K-J, Schneider H, Haak R. Assessment of defects at tooth/self-adhering flowable composite interface using swept-source optical coherence tomography (SS-OCT). Dent Mater. Mai 2015;31(5):534-41.

34. Huang D, Swanson EA, Lin CP, Schuman JS, Stinson WG, Chang W, u. a. Optical coherence tomography. Science. 22. November 1991;254(5035):1178-81.

35. Katkar RA, Tadinada SA, Amaechi BT, Fried D. Optical Coherence Tomography. Dent Clin North Am. Juli 2018;62(3):421-34.

36. Colston BW, Sathyam US, DaSilva LB, Everett MJ, Stroeve P, Otis LL. Dental oct. Opt Express. 1998;3(6):230-238.

37. Hsieh Y-S, Ho Y-C, Lee S-Y, Chuang C-C, Tsai J, Lin K-F, u. a. Dental Optical Coherence Tomography. Sensors. 12. Juli 2013;13(7):8928-49.

38. Fercher AF. Optical coherence tomography - development, principles, applications. Z Für Med Phys. November 2010;20(4):251-76.

39. Drexler W, Fujimoto JG. State-of-the-art retinal optical coherence tomography. Prog Retin Eye Res. Januar 2008;27(1):45-88.

40. Welzel J, Schuh S. [Optical coherence tomography for skin pathologies]. Ophthalmol Z Dtsch Ophthalmol Ges. Juni 2018;115(6):524-7.

41. Leistner DM, Landmesser U, Fröhlich GM. FD-OCT and IVUS for detection of incomplete stent apposition in heavily calcified vessels: novel insights. Open Heart. 2015;2(1):e000292.

42. Feldchtein F, Gelikonov V, Iksanov R, Gelikonov G, Kuranov R, Sergeev A, u. a. In vivo OCT imaging of hard and soft tissue of the oral cavity. Opt Express. 14. September 1998;3(6):239-50.

43. Park K-J, Schneider H, Haak R. Assessment of interfacial defects at composite restorations by swept source optical coherence tomography. J Biomed Opt. 22. Juli 2013;18(7):076018.

44. Bortolotto T, Bahillo J, Richoz O, Hafezi F, Krejci I. Failure analysis of adhesive restorations with SEM and OCT: from marginal gaps to restoration loss. Clin Oral Investig. November 2015;19(8):1881-90.

45. Hickel R, Roulet J-F, Bayne S, Heintze SD, Mjör IA, Peters M, u. a. Recommendations for conducting controlled clinical studies of dental restorative materials. Clin Oral Investig. 8. Februar 2007;11(1):5-33. 


\section{Darstellung des eigenen Beitrags}

Der Promovend, Marcus Hähnel, war an der vorliegenden Publikation in folgender Weise beteiligt:

- Auswertung der OCT-Daten

- Statistische Auswertung der OCT-Daten, sowie Interpretation der Ergebnisse in Zusammenarbeit mit Dr. Schneider und Dr. Rosolowski

- Mitwirkung an der Erstellung des Manuskriptes speziell in den Bereichen Material und Methoden, Ergebnisse und Diskussion

\section{bun}

Univ.-Prof. Dr. Rainer Haak

korrespondierender Autor

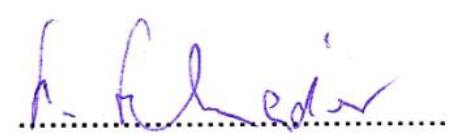

Dr. Hartmut Schneider
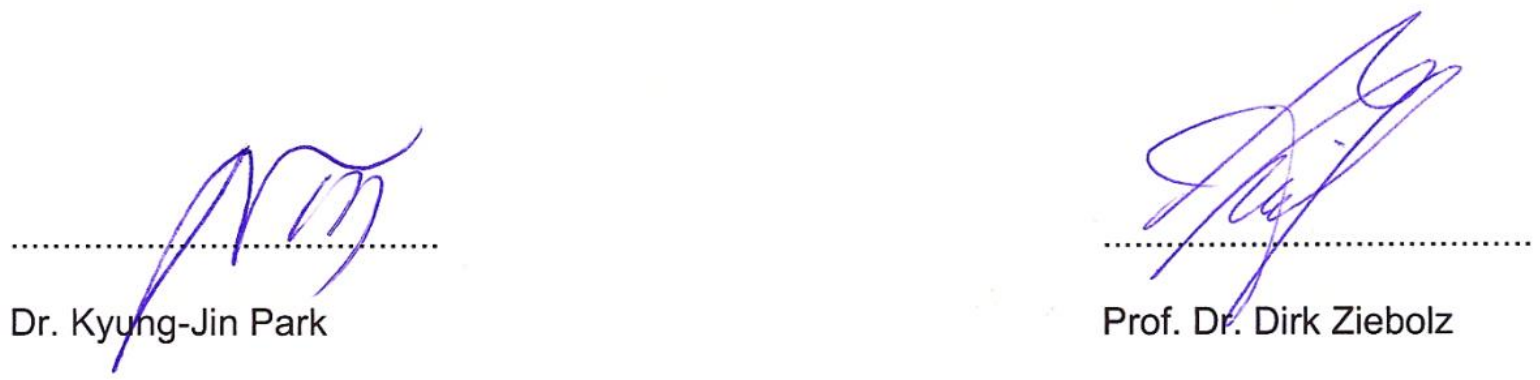

Prof. DF. Dirk Ziebolz 


\section{Selbstständigkeitserklärung}

Hiermit erkläre ich, dass ich die vorliegende Arbeit selbstständig und ohne unzulässige Hilfe oder Benutzung anderer als der angegebenen Hilfsmittel angefertigt habe. Ich versichere, dass Dritte von mir weder unmittelbar noch mittelbar eine Vergütung oder geldwerte Leistungen für Arbeiten erhalten haben, die im Zusammenhang mit dem Inhalt der vorgelegten Dissertation stehen, und dass die vorgelegte Arbeit weder im Inland noch im Ausland in gleicher oder ähnlicher Form einer anderen Prüfungsbehörde zum Zweck einer Promotion oder eines anderen Prüfungsverfahrens vorgelegt wurde. Alles aus anderen Quellen und von anderen Personen übernommene Material, das in der Arbeit verwendet wurde oder auf das direkt Bezug genommen wird, wurde als solches kenntlich gemacht. Insbesondere wurden alle Personen genannt, die direkt an der Entstehung der vorliegenden Arbeit beteiligt waren. Die aktuellen gesetzlichen Vorgaben in Bezug auf die Zulassung der klinischen Studien, die Bestimmungen des Tierschutzgesetzes, die Bestimmungen des Gentechnikgesetzes und die allgemeinen Datenschutzbestimmungen wurden eingehalten. Ich versichere, dass ich die Regelungen der Satzung der Universität Leipzig zur Sicherung guter wissenschaftlicher Praxis kenne und eingehalten habe.



Datum

Unterschrift 


\section{Wissenschaftliche Veröffentlichungen und Vorträge}

M. Hähnel, M. Häfer, P. Schmidt, H. Schneider, R. Haak,

Bewertung eines Universaladhäsivs - klinisch und mit optischer

\section{Kohärenztomografie}

Young Scientists in Dentistry - 13. Symposium für Nachwuchswissenschaftler,

Dresden, Mai 2017; Kurzvortrag.

M. Hähnel, M. Häfer, P. Schmidt, M. Rosolowski, H. Schneider, R. Haak

Progression of interfacial adhesive defects of remaining composite restorations

vs. restoration losses over a $\mathbf{3 6}$ months period

9. ConsEuro Berlin 2019,

Berlin, Juni 2019; Postervorstellung.

R. Haak, M. Hähnel, H. Schneider, M. Rosolowski, KJ. Park, D. Ziebolz, M. Häfer

Clinical and OCT outcomes of a universal adhesive in a randomized

clinical trial after 12 months

Journal of Dentistry,

September 2019; Publikation. 


\section{Danksagung}

An dieser Stelle möchte ich mich ganz herzlich bei Herrn Univ.-Prof Dr. Rainer Haak für das Vertrauen, die Unterstützung und die Möglichkeit, diese Studie unter seiner Leitung durchführen zu können, bedanken.

Ein besonderer Dank geht an meine Betreuer Dr. Matthias Häfer und Dr. Hartmut Schneider, die mir stets tatkräftig zur Seite standen, für alle Fragen offen waren und mit fachlicher Kompetenz überzeugen konnten. Ich bin sehr dankbar für die Zusammenarbeit.

Weiterhin möchte ich dem Laborteam um Claudia Rüger und Tobias Meißner danken, durch dessen Unterstützung viele Grundsteine für diese Arbeit gelegt wurden.

Tief verbunden bin ich meinen Eltern und möchte mich für ihre Unterstützung und Liebe, sowie ihr Vertrauen bedanken.

Ebenso möchte ich mich bei meiner Freundin Julia Zins bedanken. Sie hat mich nicht nur unterstützt, sondern mir außerdem in vielen Momenten Kraft und Zuspruch gegeben. Ohne ihre Hilfe wäre das Studium und die Promotion nicht in dieser Weise verlaufen.

Ein großer Dank geht außerdem an meine Freunde, die ich während meiner Studienzeit in Leipzig kennengelernt habe und mit denen ich viele schöne sowie bewegende Momente erleben durfte. 